NBER WORKING PAPER SERIES

\author{
AN INTERGENERATIONAL MODEL \\ OF WAGES, HOURS AND EARNINGS
}

Joseph G. Altonji

Thomas A. Dunn

Working Paper No. 4950

\author{
NATIONAL BUREAU OF ECONOMIC RESEARCH \\ 1050 Massachusetts Avenue \\ Cambridge, MA 02138 \\ December 1994
}

This project was funded by the U.S. Department of Labor Bureau of Labor Statistics under Contract Number J-9-J-7-0094. It was originally titled "Family Background, Labor Market Outcomes, and Race and Sex Differences in Youth Employment Outcomes". Opinions stated in this document do not necessarily represent the official position or policy of the U.S. Department of Labor. Research support from the Center for Urban Affairs and Policy Research, Northwestern University is also gratefully acknowledged. We are grateful to participants in the EMRU Labour Conference, Loughborough, England, U.K. (July 8, 1990) and to participants in seminars at RAND, NBER, and the Institute for Research on Poverty for helpful comments on an earlier draft of the paper. Alex Idichandy, Michele Borsetti, Yasuyo Abe, and James Spletzer provided skillful research assistance. We are responsible for the shortcomings of the paper. This paper is part of NBER's research program in Labor Studies. Any opinions expressed are those of the authors and not those of the National Bureau of Economic Research.

(C) 1994 by Joseph G. Altonji and Thomas A. Dunn. All rights reserved. Short sections of text, not to exceed two paragraphs, may be quoted without explicit permission provided that full credit, including $(\mathcal{O}$ notice, is given to the source. 


\title{
AN INTERGENERATIONAL MODEL \\ OF WAGES, HOURS AND EARNINGS
}

\begin{abstract}
In this paper we develop and estimate a factor model of the earnings, labor supply, and wages of young men and young women, their parents and their siblings. We estimate the model using data on matched sibling and parent-child pairs from the National Longitudinal Survey of Labor Market Experience. We measure the extent to which a set of unobserved parental and family factors that drive wage rates and work hours independently of wage rates lead to similarities among family members in labor market outcomes.

We find strong family similarities in work hours that run along gender lines. These similarities are primarily due to preferences rather than to labor supply responses to family similarities in wages. The wage factors of the father and mother influence the wages of both sons and daughters. A "sibling" wage factor also plays an important role in wage determination. We find that intergenerational correlations in wages substantially overestimate the direct influence of fathers, and especially mothers, on wages. This is because the father's and mother's wage factors are positively correlated. The relative importance for the variance in earnings of the direct effect of wages, the labor supply response induced by wages, and effect of hours preferences varies by gender, and by age in the case of women. For all groups most of the effect of wages on earnings is direct rather than through a labor supply response.
\end{abstract}

Joseph G. Altonji Department of Economics Northwestern University Evanston, IL 60208 and NBER
Thomas A. Dunn Department of Economics Syracuse University Syracuse, NY 13244-1090 and NBER 


\section{Introduction}

There is a large literature in sociology and economics on inter and intragenerational links in family income, occupation, education, and socioeconomic status. ${ }^{1}$ In contrast, few studies have investigated family relationships in work hours, or examined the relative contributions of family links in wages and in work hours to intergenerational and intragenerational correlations in income. It is common to say that an individual is from a family of "hard workers", but the question of whether leisure preferences are correlated among family members has received little study. Are there in fact similarities in work hours of family members? Do these similarities reflect labor supply responses to similarities in wages or to similarities in preferences? Are the wage rates and work preferences of young men and young women influenced primarily by fathers, mothers, or by characteristics of the family environment that are unrelated to the wages and labor supply preferences of the parents? To what extent does the correlation between the labor market outcomes of fathers and sons arise because of a direct effect of the father's characteristics on the son, and to what extent do they arise because assortative mating selects the characteristics of the mother, which then directly influence the son's labor market outcome?

This paper is a first attempt at measuring the effects of parental and "sibling" wage and work preference factors on the wages, hours, and earnings of young men and young women. We

\footnotetext{
${ }^{1}$ The literature is far to large to be discussed or even fully cited here, but examples include Corcoran and Jencks (1979), studies summarized in Becker and Tomes (1986). Recent examples are Behrman and Taubman (1990), Solon et al (1991), Solon (1992), and Zimmerman (1992). Studies such as Griliches (1979), and Hauser and Sewell (1986), and Behrman and Taubman (1989) have investigated the channels through which parental variables such as IQ, income, and education affect the cognitive ability, educational aspirations and attainment, and economic success of children. And a large number of studies use regression approaches to examine the effects of parental income and education on children's education and economic outcomes. Much of the discussion has focussed on (1) the size of the linkages in family income and education among siblings and across generations, and (2) the extent to which the linkages reflect (a) genetic factors, (b) other influences on parents that in turn affect the development of their children, and (c) neighborhood and community influences on children that operate independently of the immediate family. See Jencks and Mayer (1991) for a recent survey of the effects of neighborhood characteristics on a variety of social outcomes. They cite only a few studies which have examined the effects of neighborhood characteristics on future earnings and family income. Recent ones are Corcoran et al (1990), and Case and Katz (1991) and Borjas (1993).
} 
use intergenerational panel data from the National Longitudinal Surveys of Labor Market Experience (NLS) to estimate a model of labor earnings of young men and young women. The two key components of the model are a factor model of wage rates and a labor supply model. In the model, wages of young men and young women depend on the unobserved permanent component of the father's wage, the unobserved permanent component of the mother's wage, an unobserved sibling component representing background characteristics that are common to siblings but independent of the parents' factors, and an unobserved factor that is specific to each individual. Work hours depend on wages as well as labor supply preferences. Labor supply preferences of young men and young women depend on the father's preferences, the mother's preferences, a preference factor that is common to siblings, and an idiosyncratic preference factor. Finally, earnings depend upon wages and hours. Since the underlying variables driving preferences, wages, hours, and earnings are unobserved, the model is a factor model. Since we are interested in gender differences in the determination of wages, earnings, and hours, most of the model parameters are gender specific. We estimate the model parameters by fitting the model to the autocovariances and cross-covariances of hours, wages, and earnings for the young men and young women, and their fathers, mothers, and siblings who can be identified in the data sets. ${ }^{2}$

We work with a factor model because such models are well suited to the task of measuring the overall importance of various family links, particularly given that observed wages, hours and earnings in a particular year are heavily influenced by measurement error and transitory factors, and given that we know very little about what observed characteristics of the parents, home, neighborhood, or schools are likely to influence hours preferences or about how to

\footnotetext{
2 To our knowledge, this study is the first to use intergenerational and sibling covariances in wage rates to identify labor supply elasticities.
} 
measure hours preferences directly. ${ }^{3}$ We are able to use the factor model to measure the relative contributions of the wage and the reference factors of siblings, the father, and the mother to each of the variances and covariances. We can distinguish between a direct contribution of the wage factors to family covariances in earnings and indirect contribution that arise from the labor supply response.

The paper proceeds as follows. In section I we present the factor model of earnings, hours, wage rates and preferences. We also discuss our approach to estimating the model and how the model can be used to decompose the variances and covariances of labor market outcomes. In section II we discuss the data and estimation issues. In section III we discuss the estimates of parameters of the the work preference, wage, hours, and earnings equations. In section IV, we present the variance and covariance decompositions. We discuss the implications of the results and a research agenda in section $\mathrm{V}$.

\section{A Factor Model of Preferences, Wages, Hours and Earnings}

In this section we specify a factor model of the permanent components of earnings, hours, and wage rates which dominate differences across individuals in lifetime income. The model consists of equations relating the wages and work preferences of young men and women to unobserved parental factors, "sibling" factors that are common to children from the same family but are uncorrelated with the parental factors, and individual specific factors. We also specify labor supply equations for young men and women and older men and women that relate work hours to wages and to work preferences. Finally, we specify that earnings depend on wages and work hours, and make a set of assumptions about the covariances between the various unobserved factors in the model. We then discuss how the model may be used to analyze the

\footnotetext{
${ }^{3}$ We note in the conclusion that the large role of the family in work hours that we find calls for research relating work hours to characteristics of the parents and home and to childhood experiences that might plausibly influence hours preferences.
} 
sources of variation in labor market outcomes and how the model may be estimated.

\section{I.1 Labor Supply Equations}

The labor supply equations for young women, young men, mature women, and older men have the following form:

(1) $\mathrm{H}_{\mathrm{ik}}=\beta_{\mathrm{k}} \mathrm{W}_{\mathrm{ik}}+\mathrm{U}_{\mathrm{ik}}$

(2) $\mathrm{H}_{\mathrm{ikt}}=\mathrm{H}_{\mathrm{ik}}+\mathrm{e}_{\mathrm{ikt}}$

where

$$
\begin{aligned}
& \mathrm{i}=\text { family indicator, } \\
& \mathrm{k} \quad \begin{array}{l}
\text { = person type, where } \mathrm{k}=\mathrm{b} \text { for young men (sons), } \mathrm{g} \text { for young women } \\
\text { (daughters), f for older men (fathers) and } \mathrm{m} \text { for mature women (mothers), }
\end{array} \\
& \mathrm{t} \quad \text { = year indicator, } \\
& \mathrm{H}_{\mathrm{ik}} \quad \text { = the permanent value of the log of annual hours worked by person } \mathrm{ik}, \\
& \mathrm{H}_{\mathrm{ikt}} \quad \text { = log of measured annual hours worked by person ik in year } \mathrm{t}, \\
& \mathrm{W}_{\mathrm{ik}} \quad \text { = permanent wage of person ik, } \\
& \mathrm{U}_{\mathrm{ik}} \quad \text { = permanent component of hours preferences of ik, and } \\
& \mathrm{e}_{\mathrm{ikt}} \quad=\text { transitory determinants of hours and measurement error. }
\end{aligned}
$$

Since there may be more than one son and/or daughter in family $i$, the subscript $k$ is implicitly indexed by the person number $j$, and we add this index when it is needed for clarity.

We refer to $U_{i k}$ as the preference component of hours. For simplicity, we have normalized its coefficient to unity. The life cycle model of labor supply suggests that interpreting $\mathrm{U}_{\mathrm{ik}}$ in (1) as a preference shifter is an oversimplification. From the point of view of that model, $\beta_{k}$ is the response of labor supply to a shift upward in the entire profile of lifetime wages. The term $U_{i k}$ consists of the effects of preferences for goods and leisure on the marginal utility of 
lifetime income, and the direct effect of leisure preferences on labor supply. Later we will introduce the assumption that bequests and family transfers other than human capital investments of parents in children are unimportant. In this case similarities across family members in parental wealth should not produce large covariances in the marginal utility of incomes of relatives once we control for similarities in the permanent wage rates. However, if bequests and transfers are important, then our interpretation of $\mathrm{U}_{\mathrm{ik}}$ as "hours preferences" is incorrect, and, perhaps more importantly, the assumption made below that $\operatorname{Cov}\left(U_{i k}, W_{i k^{\prime}}\right)=0$ for $k=g$ or $b$, and $k^{\prime}=m$ or $f$ would be unlikely to hold; that is, parents' wages may influence children's preferences for working. ${ }^{4}$

\section{I.2 Earnings Equations}

Equation (2) specifies that the permanent component of log earnings $\mathrm{E}_{\mathrm{ik}}$ depends upon the log permanent wage $\mathrm{W}_{\mathrm{ik}}$ and the $\log$ permanent hours level $\mathrm{H}_{\mathrm{ik}}$. Observed earnings for person $\mathrm{ik}, \mathrm{E}_{\mathrm{ikt}}$, is equal to $\mathrm{E}_{\mathrm{ikt}}$ plus the term $\epsilon_{\mathrm{ikt}}$ that captures transitory influences and measurement error:

(3) $\mathrm{E}_{\mathrm{ikt}}=\phi_{\mathrm{kw}} \mathrm{W}_{\mathrm{ik}}+\phi_{\mathrm{kh}} \mathrm{H}_{\mathrm{ik}}+\epsilon_{\mathrm{ikt}}$

After substituting (1) into (3) the log earnings equation is

(4) $\mathrm{E}_{\mathrm{ikt}}=\left[\phi_{\mathrm{kw}}+\phi_{\mathrm{kh}} \beta_{\mathrm{k}}\right] \mathrm{W}_{\mathrm{ik}}+\phi_{\mathrm{kh}} \mathrm{U}_{\mathrm{ik}}+\epsilon_{\mathrm{ikt}}$

4. The available evidence suggests that transfers are only weakly related to the incomes of parents and their adult children and that transfers are a small component of the incomes of adult children. See Altonji, Hayashi and Kotlikoff (1992), Dunn (1993)and Shoeni (1993), who provide additional references. Joulfaian and Wilhelm (forthcoming) find only a small effect of inheritances and expected inheritances on labor supply. 
Note that $\mathrm{W}_{\mathrm{ik}}$ and the permanent preference component $\mathrm{U}_{\mathrm{ik}}$ alone determine earnings and hours. Consequently, family linkages in earnings, hours, and wages are determined by family links in $\mathrm{W}_{\mathrm{ik}}$ and in $\mathrm{U}_{\mathrm{ik}}$, which we now specify.

\section{I.3 Family Links in Wages}

In equations $(5 a, 5 b)$ we specify that the permanent wages $W_{i g}$ and $W_{i b}$ of young women and men are determined by the permanent wages of their fathers and mothers, a family specific (or sibling) factor that is independent of the parental wage components, and an idiosyncratic factor:

(5a) $W_{\text {ig }}=a_{\text {gf }} W_{\text {if }}+a_{\text {gm }} W_{\text {im }}+a_{\text {gs }} \omega_{\text {is }}+\omega_{\text {ig }}$

(5b) $w_{i b}=a_{b f} W_{i f}+a_{b m} w_{i m}+a_{b s} \omega_{i s}+\omega_{i b}$

where

$\mathrm{W}_{\text {if }}=$ father's permanent wage component,

$\mathrm{W}_{\mathrm{im}}=$ mother's permanent wage (or potential wage if not working),

$\omega_{\text {is }}=$ a sibling factor reflecting common genetic or environmental factors that affect wages of children from family $i$ independent of $W_{i f}$ and $W_{i m}$, and

$\omega_{i k}=$ idiosyncratic component affecting a particular young man $(k=b)$ or young woman $(k=g)$ from household $i$.

We assume that the observed wage rate $W_{i k t}$ is equal to the permanent wage $W_{i k}$ plus an MA(2) error component, $\mathrm{v}_{\mathrm{ikt}}$, representing transitory factors and measurement error:

(6) $W_{i k t}=W_{i k}+v_{i k t} \quad$ for $k=b, g, f$, and $m$.

\section{I.4 Family Links In Preferences}

Our gender specific factor model for children's preferences $U_{i b}$ and $U_{i g}$ has the same form as the model for their wages. Specifically,

(7a) $\mathrm{U}_{\text {ig }}=\lambda_{\text {gf }} \mathrm{U}_{\text {if }}+\lambda_{\text {gm }} \mathrm{U}_{\mathrm{im}}+\lambda_{\mathrm{gs}} \mathrm{u}_{\text {is }}+\mathrm{u}_{\mathrm{ig}}$

(7b) $\mathrm{U}_{\mathrm{ib}}=\lambda_{\mathrm{bf}} \mathrm{U}_{\mathrm{if}}+\lambda_{\mathrm{bm}} \mathrm{U}_{\mathrm{im}}+\lambda_{\mathrm{bs}} \mathrm{u}_{\mathrm{is}}+\mathrm{u}_{\mathrm{ib}}$ 
where

$$
\begin{aligned}
& \mathrm{U}_{\mathrm{if}}=\text { father's permanent preference component, } \\
& \mathrm{U}_{\mathrm{im}}=\text { mother's permanent preference component, } \\
& u_{i s}=\text { common genetic or environmental factors that affect work preferences of children } \\
& \text { from family } i \text { independent of } U_{i f} \text { and } U_{i m}{ }^{--} \text {we refer to } u_{i s} \text { as the sibling preference } \\
& \text { factor, and } \\
& \mathrm{u}_{\mathrm{ik}}=\text { idiosyncratic preference component affecting a particular young man }(\mathrm{k}=\mathrm{b}) \text { or } \\
& \text { young woman }(k=g) \text { from household } i \text {. }
\end{aligned}
$$

\section{I.5 Relationships Among the Wage and Preference Factors}

Our assumptions about the preference factors $U_{i f} U_{i m}, u_{i s}, u_{i b}, u_{i g}$, and the wage factors $\mathrm{W}_{\text {if }}, \mathrm{W}_{\mathrm{im}}, \omega_{\mathrm{is}}, \omega_{\mathrm{ib}}$, and $\omega_{\mathrm{ig}}$ are as follows. First, we assume that they all are unrelated to the transitory components in hours, earnings, and wages which we denote by $e_{i k t}, \epsilon_{i k t}$, and $v_{i k t}$ respectively. Second we assume that covariances within the set of preference factors and within the set of wage factors are zero, with the exception of the covariance between the parents' preference factor $\left(\operatorname{Cov}\left(\mathrm{U}_{\mathrm{if}} \mathrm{U}_{\mathrm{im}}\right)\right)$ and between the parents' wage factors $\left(\operatorname{Cov}\left(\mathrm{W}_{\text {if }} \mathrm{W}_{\mathrm{im}}\right)\right)$. (These two covariances will be estimated.) The third assumption, which will be discussed momentarily, is that all the preference factors are uncorrelated with all the wage factors.

We define $\omega_{\text {is }}$ to capture influences on permanent wages that are common to siblings and are not uncorrelated with the parents' wage factors. $\left(\operatorname{Cov}\left(\omega_{i s}, w_{i f}\right)=\operatorname{Cov}\left(\omega_{i s}, w_{i m}\right)=0\right)$. Any residual variation in wages is attributed to the idiosyncratic components $\omega_{i b}$ or $\omega_{i g}$. These are defined to be orthogonal to $\omega_{\text {is }}, \mathrm{W}_{\mathrm{if}}$ and $\mathrm{W}_{\mathrm{im}}$. They are uncorrelated across siblings. One can always perform such a decomposition, although $\omega_{i s}, \omega_{i g}$, and $\omega_{i b}$ have clean interpretations as family influences and person specific influences only if there are no interactions between common 
parent and siblings influences and person specific influences. ${ }^{5}$ Similar remarks apply to the preference factors $u_{i s}, u_{i b}$, and $u_{i g}$.

Without additional indicators for preferences or components of the wage rate, one must make an identifying assumption about the relationship between preferences and the permanent wage rate. Our assumption that preferences are independent of the wage determinants is a particularly convenient one. It is also in line with standard practice in the literature on male labor supply. Most studies assume that wages are unrelated to preferences once one controls for a small number of demographic variables that typically explain very little of the variance in work hours. ${ }^{6}$ However, one might argue that leisure preferences have a direct effect on study time in elementary school, high school and college, as well as hours worked per year once one enters the labor market-- all of which may influence wage rates. Also, joint models of labor supply and human capital investment predict a positive relationship between schooling, on-the-job training, and preferences for market work. ${ }^{7}$

Special problems arise in the case of women, because hours of market work are a poor measure of the total labor supply of married women with children. Variables such as attitudes toward raising children that influence the allocation of time between market and nonmarket work

5. The sibling factor $\omega_{\text {is }}$ may be a function of a large number of characteristics. One can summarize the influence of these characteristics with one factor provided that the function does not depend on the idiosyncratic characteristics of a particular young man or young women. Otherwise, $\omega_{i s}, \omega_{i g}$ and $\omega_{i b}$ provide a statistical decomposition of the set of interdependent family and person specific variables into a component that is common to siblings and one that is specific to the individual, while ignoring any interaction effects. For example, if the effect of neighborhood characteristics on the log permanent wage depends upon the IQ of the individual, then the dissimilarity of wage rates of brothers who have different IQs will change as one changes the neighborhood characteristics.

6. See Pencavel (1986). Some studies use instruments to control for preferences, but we do not find discussions of why particular variables, such as schooling, are exogenous to be particularly convincing. The use of instruments is also motivated as a means of reducing problems associated with measurement error in earnings divided by hours or to deal with missing data on wages for those who work zero hours. Our methods are not sensitive to transitory measurement error provided that it is an MA (2) or less.

7. We estimate the model using residuals of earnings, hours, and wages from a cubic in age. The residuals will be uncorrelated with lifecycle related variation in preferences and wages. 
are likely to influence schooling and job training choices. ${ }^{8}$ In future work, it would be interesting to add measures of nonmarket work (such as housekeeping, child care, care of relatives, and volunteering) to the hours of paid employment.

\section{I.6 Assumptions About the Transitory Components of Wages, Hours, and Earnings \\ We assume the transitory components $\left(v_{i k t}, e_{i k t}\right.$, and $\left.\epsilon_{i k t}\right)$ are uncorrelated across}

different extended families $i$ and across individuals within the same family. ${ }^{9}$ Formally,

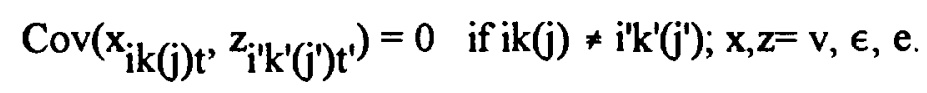

We assume that the autocovariances and cross covariances of $\mathrm{e}_{\mathrm{ikt}}, \epsilon_{\mathrm{ikt}}$, and $\mathrm{v}_{\mathrm{ikt}}$ over time for a given individual are zero for observations that are more than two years apart. Formally,

(9) $\operatorname{Cov}\left(x_{i k(j) t}, z_{i k(j) t}\right)=0$ if $\left|t-t^{\prime}\right|>2 ; x, z=v, \epsilon, e$.

We are ignoring any persistent shocks to earnings, hours, or wages.

\section{I.7 Some Limitations of the Model}

We deal with non-participation in the labor market by excluding observations in which an individual did not work from the analysis. Individuals who never work are excluded entirely. Unfortunately, we do not have wage data for such individuals. Furthermore, limited dependent variables techniques (which would allow us to remedy this problem) are very difficult to handle in

\footnotetext{
${ }^{8}$. See Mincer and Polachek (1974), Polachek (1978) and Blakemore and Low (1981). For an opposing view emphasizing the role of discrimination, see England (1982).

9. This assumption could fail to the extent that relatives are in the same industry, occupation or region, and that shifts in these variables are important for wage and hours determination. In such a case, the covariances among family members' variables would probably be overstated. However, we believe the bias is likely to be small, both because we suspect industry, occupation, and regional factors are unimportant relative to job specific and person specific factors, and because most pairs of year specific observations for the relatives that are used to compute the covariances are drawn from different years.
} 
models with a large number of unobserved factors. Consequently, we leave this extension to future research while recognizing its potential importance. ${ }^{10}$

The model is also restrictive in the treatment of family labor supply. First, we have already mentioned that we ignore altruistic linkages among relatives that would imply cross substitution effects of wage rates on hours of work. We do not view this as a serious misspecification. A larger concern is that we also exclude the spouse's wage for those individuals who are married, which means that we are treating the labor supply of husbands and wives as separate decisions. Other researchers have found a negative effect of husband's earnings or wages on the wife's work hours. (See Killingsworth and Heckman (1986).) Since there is evidence in Altonji and Dunn (1991) and other studies that their wages are positively correlated, this omission could lead to biases in our estimated labor supply elasticities. One could relax this assumption by

10. Out of 1848 mother-daughter pairs, 296 are lost because the daughter dropped out of the sample before age 24 and/or before leaving school. The log of work hours, age at the start of the sample, and education of the mother and daughter in the remaining 1552 cases that are potentially eligible for inclusion in the analysis are as follows.

\begin{tabular}{|c|c|c|c|c|c|c|c|}
\hline \multirow[b]{2}{*}{ Sample: } & \multirow[b]{2}{*}{$\begin{array}{l}\% \text { of } \\
\text { Cases } \\
\end{array}$} & \multicolumn{3}{|c|}{ Daughter } & \multicolumn{3}{|c|}{ Mother } \\
\hline & & $\begin{array}{l}\text { Age } \\
\text { in } 68 \\
\end{array}$ & $\begin{array}{l}\text { Educ- } \\
\text { ation }\end{array}$ & $\begin{array}{l}\text { Log } \\
\text { Hours }\end{array}$ & $\begin{array}{l}\text { Age } \\
\text { in } 68 \\
\end{array}$ & $\begin{array}{l}\text { Educ- } \\
\text { ation }\end{array}$ & $\begin{array}{l}\text { Log } \\
\text { Hours }\end{array}$ \\
\hline $\begin{array}{l}\text { Both Mother } \\
\text { and Daughter } \\
\text { Worked at } \\
\text { Least Once }\end{array}$ & 59.8 & 17.2 & 13.0 & 7.11 & 41.0 & 10.5 & 6.96 \\
\hline $\begin{array}{l}\text { Mother Worked, } \\
\text { Daughter Did } \\
\text { Not }\end{array}$ & 22.2 & 16.9 & 12.1 & - & 40.8 & 10.4 & 6.95 \\
\hline $\begin{array}{l}\text { Daughter Worked } \\
\text { Mother Did Not }\end{array}$ & 11.7 & 17.3 & 12.7 & 7.08 & 42.7 & 9.6 & - \\
\hline $\begin{array}{l}\text { Neither Mother } \\
\text { Nor Daughter } \\
\text { Worked }\end{array}$ & 6.3 & 17.1 & 11.6 & - & 41.6 & 9.6 & - \\
\hline
\end{tabular}

The unconditional probability that a daughter does not work is 285 . The probability that a daughter does not work conditional on the mother not working is .350 . The means of log hours of mothers and of daughters are not very sensitive to whether or not the other works. The fact that the education levels are lower for those who do not work than for those who do is consistent with the positive labor supply elasticities we obtain. We do not wish to push these summary statistics too far, but they provide at least some suggestion that dealing with labor force participation will not dramatically change our conclusions. 
constructing separate labor supply equations for married and unmarried individuals. To do this or to analyze other linkages among extended family members-- for example, between fathers and sons-in-law-- it will be necessary to add equations relating marital status and the expected value of the permanent wage and hours preferences of the husband to the parental, family, and idiosyncratic factors of the young woman. This complicates matters considerably, and so we feel that it is preferable in an initial study to work with the simpler model presented here.

\section{I.8 Fitting the Model and Variance Decompositions}

The model parameters described above consist of the coefficients in the preference, wage, hours, and earnings equations, the variances of the wage and preference factors, and the covariances of wage and preference factors of the parents. These parameters determine the variances and covariances among the labor market outcomes of young men and young women as well as covariances between the labor market variables of children and parents, and among siblings. For example, equation (5b) implies that the covariance between the wages of brothers $j$ and $\mathrm{j}^{\prime}$ is

(10) $\operatorname{Cov}\left(W_{i b(j)}, W_{i b\left(j^{\prime}\right)}\right)=\operatorname{Cov}\left(W_{i b(j) t}, W_{\left.i b\left(j^{\prime}\right) t^{\prime}\right)}\right.$

$$
\begin{aligned}
& =a_{b f}{ }^{2} \operatorname{Var}\left(W_{i f}\right)+a_{b m}{ }^{2} \operatorname{Var}\left(W_{i m}\right) \\
& +2 a_{b m} a_{b f} \operatorname{Cov}\left(W_{i f} W_{i m}\right)+a_{b s}{ }^{2} \operatorname{Var}\left(\omega_{i s}\right),
\end{aligned}
$$

for $\mathrm{j} \neq \mathrm{j}^{\prime}$, and for all $\mathrm{t}$ and $\mathrm{t}^{\prime}$.

The variance of young men's wages can be constructed from (5b) as follows

(11) $\operatorname{Var}\left(W_{i b(j)}\right)=\operatorname{Cov}\left(W_{i b(j) t}, W_{i b(j) t}\right)$

$$
\begin{aligned}
= & a_{b f}{ }^{2} \operatorname{Var}\left(W_{i f}\right)+a_{b m}{ }^{2} \operatorname{Var}\left(W_{i m}\right)+2 a_{b m} a_{b f} \operatorname{Cov}\left(W_{i f} W_{i m}\right) \\
& +a_{b s}{ }^{2} \operatorname{Var}\left(\omega_{i s}\right)+\operatorname{Var}\left(\omega_{i b}\right),\left|t-t^{\prime}\right|>2 .
\end{aligned}
$$


Equation (11) may be used to assess the contribution of the parental variables to the variance in the permanent wages of young men. The father's contribution is $a_{b f}{ }^{2} \operatorname{Var}\left(W_{i f}\right)$ plus the portion of the covariance term $2 a_{b m} a_{b f} \operatorname{Cov}\left(W_{i f} W_{i m}\right)$ that is assigned to the father. The contributions of the mother's wage $\mathrm{W}_{\mathrm{im}}$, the family factor $\omega_{\mathrm{is}}$, and the idiosyncratic factor $\omega_{\mathrm{ib}}$ to the variance of the wages of young men are clearly laid out in the equation. The contributions of the various components to the brothers' wage covariance (equation 10) are the same as the contributions to the young men's variance, except that the idiosyncratic factor $\omega_{i b}$ which is uncorrelated across brothers, plays a role in (11) but not in (10). In Table 2 below we plug the estimated parameter values from Table 1 into formulae similar to (10) and (11) for other key variance and covariances, ${ }^{11}$ and measure the contributions of the various wage and preference factors to the estimated variances and covariances.

\section{I.9 Estimation}

The parameters of the model are estimated by fitting the theoretical variances and covariances implied by equations (2), (4), (5), (6) and (7) to the sample estimates of the corresponding variances and covariances. There are 90 unique theoretical autocovariances and cross-covariances. ${ }^{12}$

We refer to our sample estimates of the variances and covariances as the sample moments, which we compute as follows. We first take the residuals from regressions of each of the labor market variables against a cubic in age and a set of year dummies. We compute family covariances of a particular labor market outcome by computing the unique set of crossproducts of the elements of the vector of labor market outcomes in different years for one family member with

\footnotetext{
11. As another example, using equation (4), the covariance of daughters' and fathers' earnings is given by $\operatorname{Cov}\left(E_{i g}, E_{i f}\right)=\left[\phi_{g w}+\phi_{g h} \beta_{g}\right]\left[\phi_{f w}+\phi_{f h} \beta_{f}\right] \operatorname{Cov}\left(W_{i g}, W_{i f}\right)+\left[\phi_{g h} \phi_{f h}\right] \operatorname{Cov}\left(U_{i g}, U_{i f}\right)$

12. In Appendix Table A2 we present the sample estimates of the 90 unique variances and covariances of key variables and the corresponding correlation coefficients and sample sizes, but omit discussion of them to save space.
} 
the elements of the vector of labor market outcomes of the other family member, and taking the mean of all the crossproducts for all of the pairs of family members. We estimate the variance of the permanent component of labor market outcomes for say, young men, by first computing the crossproducts of all unique pairs of yearly observations on a labor market outcome that are for the same individual and that are separated by more than two years in time and then taking the average of all of the crossproducts for all individuals. ${ }^{13}$ We do the same for young women's, mature women's, and older men's variables. The specific formulae for these method of moments estimators of covariances, variances, and correlations are given in Appendix 1.

The samples used in estimation differ substantially for the different moments. This is bcause a given family may not supply observations to all of the matched samples on family members and because not all matched individuals provide the same number of valid reports. We assume that the model parameters are the same for all families and in particular are not related to patterns of data availability. If this homogeneity assumption is false, then our estimates of the family linkages will be biased.

We fit the theoretical model to the sample moments by weighted least squares (WLS). The WLS procedure weights each observation corresponding to one of the 90 sample moments by an estimate of its sampling variance, which we compute using an estimator discussed in

\footnotetext{
13. If a labor market variable such as the wage rate is equal to a fixed component and a transitory component that can be represented by a moving average process of order 2 or less, then the transitory component will not bias our variance estimates.
} 
Appendix $1{ }^{14}$ The WLS standard errors do not account for correlation in the sampling errors across different sample moments. ${ }^{15}$

\section{Data}

The data are from the four original cohorts of the National Longitudinal Surveys of Labor Market Experience. Specifically, we work with the sample of Young Men who were 14 to 24 years old in 1966, the samples of Young Women who were 14 to 24 in 1968, Mature Women who were 30 to 44 years old in 1967, and the sample of Older Men who were 45 to 59 in 1966. We use data through 1981 in the case of young men (when the cohort study was ended), 1982 in the case of the young women, 1984 in the case of mature women, and 1983 in the case of older men. Some of the households contributed more than one person to the young men and young women surveys, and some households contributed to both the youth surveys and older men and mature women surveys. Consequently, it is possible to match data on sibling pairs and parentchild pairs. ${ }^{16} 17$

\footnotetext{
${ }^{14}$ Altonji and Segal (1994) recommend against using WLS or optimal minimum distance procedures when fitting models of covariance structures to second moments because of bias in small samples in many situations. However, the maximum sample size they consider in their Monte Carlo work is 1,000 , while the sample sizes used to fit the sample moments in this study always exceed 3487 and are often above 7,000. We discuss the OLS estimates in footnote 19.
}

15. We have chosen not to use a full GLS estimator that would account for correlation in the sampling errors of the sample moments because of the difficulties in getting good estimates of the correlations among the sample moments when the sample is highly unbalanced and because Altonji and Segal (1994) present Monte Carlo evidence suggesting that WLS is preferred to full GLS when fitting large covariance structures with an estimated weight matrix.

16. The following is a list of potential cohort sizes and numbers of family member matches before the screens for age, schooling and retirement status are applied to the data. The four original NLS cohorts consist of 5225 young men, 5159 young women, 5020 older men, and 5083 mature women. There are potentially 621 brother pairs, 646 sister pairs, and 1921 brother-sister pairs; all these samples include multiple sibling sets from the same household. Also, there are 1099 matched father-son pairs, 988 father-daughter pairs, 1671 mother-son pairs, and 1848 mother-daughter pairs. Again, the parent-child set includes pairs with the same parent matched to more than one child. Finally, there are 345 matched fathers and mothers; that is, older men and mature women who report each other as spouses and have between them at least one child in the younger cohorts.

17. The very fact that it is possible to match data across NLS cohorts may lead to biases in the estimates of the family linkages, but the evidence in Altonji and Dunn (1991) does not point to bias in a particular direction. 
We use as many of the yearly reports as possible for each individual, subject to the following selection rules. The data for a particular variable may be missing either because the individual left the sample prior to that year's survey or because the response is missing or invalid for other reasons. We restrict the sample to individuals who were at least 24 years old prior to leaving the survey. We chose this age cutoff to reduce the influence of transitory variation in labor market outcomes associated with the transition between school and work. We use labor market data from a particular year only if the individual was at least 24 , was out of school and did not return to school in a subsequent year, was less than 61 , and had not yet retired. ${ }^{18}$

For all four cohorts we excluded wage observations of less than $\$ .40$ per hour, and earnings of less than $\$ 100$ per year (both in 1967 dollars). Also, only annual hours (constructed as reported number of weeks worked times reported number of hours worked per week) greater than zero and less than 5000 hours were counted.

\section{Estimates of Preference, Wages, Hours, and Earnings Equations}

In this section we discussion of the parameter estimates and the overall fit of the equations. Before turning to the results it is necessary to discuss a few additional restrictions that are imposed upon the model's parameters prior to estimation. Without loss of generality we normalize the son's sibling wage factor parameter, $\mathrm{a}_{\mathrm{bs}}$, to unity. Consequently, the daughter's coefficient $\mathrm{a}_{\mathrm{gs}}$ is the effect of the family wage factor $\omega_{\text {is }}$ on young women relative to the effect on young men. We also normalize both the son's and daughter's sibling preference factor coefficient, $\lambda_{\mathrm{bs}}$ and $\lambda_{\mathrm{bg}}$, to unity. Models in which this restriction is relaxed are not empirically

18 The last two restrictions will minimize problems associated with the fact that earnings, work hours, and wage rates of such individuals after retirement may not be closely related to the typical or "permanent" values for these individuals over their careers. Since the age in 1966 of the older men ranges from 45 to 59 , there is substantial variance in the number of years of labor market data available. Retirement is not a concern for the mature women's sample through the years we study. 
identified. For some of our models, we restricted the earnings equation parameters $\phi_{\mathrm{kw}}$ and $\phi_{\mathrm{kh}}$ on wages and hours to unity on the grounds that both log hours and the log wage should have coefficients of 1 in an equation for log earnings. Relaxing these restrictions produces coefficients on wages and hours which are, for the most part, reasonably close to unity. To save space, we will focus our discussion on the model that does not restrict $\phi_{\mathrm{kw}}$ and $\phi_{\mathrm{kh}}$ to unity. ${ }^{19}$

The equations for the preferences and wages of young men and young women are in the top two panels of Table 1. The father's preferences $U_{\text {if }}$ have a coefficient of .215 with a standard error of .072 in the equation for $U_{i b}$, the young men's preferences. In the same equation, the mother's preferences have a small negative coefficient which is statistically insignificant. Conversely, the father's preferences, $U_{\text {if }}$ have a negative but insignificant effect on the preferences of young women, while the mother's preferences have a coefficient (standard error) of $.368(.081)$. In summary, parental labor supply preferences have an important effect on labor supply preferences. The links depend on gender, with the father playing a strong positive role for young men and the mother playing an even stronger positive role for young women. ${ }^{20}$

The estimates of the standard deviations of the young men's and older men's preferences, $\sigma_{\mathrm{u}_{\mathrm{ib}}}$ and $\sigma_{\mathrm{u}_{\mathrm{if}}}$, are .142 and .179 , respectively. The corresponding estimates for young women and mature women, $\sigma_{u_{i g}}$ and $\sigma_{u_{i m}}$, are substantially larger at .444 and .351. The gender difference in $\sigma_{u}$ is reflection of the greater variability in the hours of women. The sibling preference factor $u_{i s}$ has an estimated standard deviation $\left(\sigma_{u_{i s}}\right)$ of .066 and enters the preference

19 Table A3 reports the WLS estimates with the restrictions on the wage and hours parameters in the earnings equations.

20 These results reflect the fact that in Table A2 that the father-son and father-daughter correlations in hours are .228 and .0012 while the mother-son and mother-daughter correlations are .070 and .238 . The estimated correlation between the parental hours preference factors $U_{\text {if }}$ and $U_{\text {im }}$ is 254 . 
equations with coefficients that have been normalized to unity. Consequently, it plays an important role in the variation in preferences for both young men and young women.

The equations for the wages of young men $\left(\mathrm{W}_{\mathrm{ib}}\right)$ and young women $\left(\mathrm{W}_{\mathrm{ig}}\right)$ show strong and statistically significant effects of the parental factors. The coefficients (standard errors) on the father's and mother's wages, $\mathrm{W}_{\mathrm{if}}$ and $\mathrm{W}_{\mathrm{im}}$, in the young men's wage equation are $280(.033)$ and $.258(.037)$, respectively. The corresponding coefficients in the young women's wage equation are .282 and .209 , both of which are significant. The sibling factor has a coefficient of .831 in the equation for $\mathrm{W}_{\mathrm{ig}}$ with a standard error of .183. This estimate falls short of the corresponding coefficient of 1 in the young men's wage equation, but by less than one standard error. Thus, we find that the mother's and father's wage factors have similar effects that are substantial. We have little evidence that these effects or the effect of the sibling factor $\omega_{\text {is }}$ depend much on the gender of the child.

The parents' wage factors have an estimated covariance equal to .054 which implies a correlation between the wage factors of .369 . Thus there is substantial positive marital sorting on the wage factor. The corresponding correlation between the hours preference factors is 254 .

We now turn to the estimates of the labor supply equations (1) and (2), which are reported in the bottom left hand side panel of Table 1 . The uncompensated labor supply elasticities (standard errors) are $.056(.015)$ for young men, $.077(.027)$ for older men, $.184(.045)$ for young women, and $.445(.043)$ for mature women. The small estimates for men are basically consistent with a large body of evidence. The results for young women are on the low side but are consistent with the conclusions of Mroz' (1987) study of static labor supply for married women. The estimate for the mature women is well within the wide range of estimates available for women, but larger than the estimates suggested by Mroz' work. Overall, these labor supply elasticities estimates seem reasonable. 
The estimated coefficients on wages and hours in the earnings equations $\left(\phi_{\mathrm{kw}}\right.$ and $\phi_{\mathrm{kh}}$, $k=b, g, f$ and $m$ ) are close to unity in all cases except for the older men's hours coefficient which is found to be .551 with a standard error of .294 . The model's parameter estimates are not very sensitive to whether or not we restrict the wage and hours parameters to unity in the earnings equation. (Compare Table 1 to Table A3.) $)^{21}$

How well does the model fit the data? The factor model, which has 33 free parameters, explains 99 percent of the variance of the 90 unweighted sample moments. Since we do not know the covariances among the sampling errors in the moments, we cannot perform a formal test of the factor model as a description of the sample moments. However, if the covariances among the sampling errors are zero, then the weighted sum of squared errors of the model has a $\chi^{2}$ distribution with $(90-33=57)$ degrees of freedom. Judged against this distribution, the model's weighted sum of squared errors of 35.10 has a p-value of .99 . Since the covariances are not independent, this goodness of fit test may be biased either for or against the factor model. However, we conclude that the parameter estimates are basically sensible and that the model fits the family covariances well enough to be used to perform variance decompositions.

\section{Decomposing the Variances and Covariances Among Labor Market Outcomes}

Tables $2 a, 2 b$, and $2 c$ examine the contributions of each of the wage and preference factors to the variances of permanent wages, hours, and earnings of young men and young

21. The labor supply elasticities rise when the restrictions are imposed. When we estimate the unrestricted model by OLS (not reported) the estimated wage factor coefficients and the estimated standard deviations of the wage factors are quite close to the WLS estimates in Table 1 . The estimated labor supply elasticities in the OLS model are consistently smaller than the WLS estimates, especially the father's. The OLS hours and wage coefficients in the earnings equations are also quite close to the WLS estimates, except for the father's hours coefficient, which is 1.30 . The only economically important difference between the OLS and WLS estimates is that the OLS estimates imply that both parental preference factors $U_{i f}$ and $U_{i m}$ have larger effects on $U_{i g}$ than on $U_{i b}$. The OLS parameter estimates seem anomalous because the implied predicted values of the covariances between the hours of parents and children and between siblings fit the corresponding sample moments poorly. The OLS estimates of the standard deviations of the wage and preference factors are very close to the WLS estimates. 
women, and to the covariances of these three variables among siblings and parent-child pairs. The decompositions presented in the tables are based on the parameter estimates in Table 1. The first column of each row lists the particular covariance or variance that we are examining. For example, in the first row of the Table $2 \mathrm{a}$ we examine $\operatorname{Cov}\left(\mathrm{W}_{\mathrm{ib}(\mathrm{j})}, \mathrm{W}_{\mathrm{ib}\left(\mathrm{j}^{\prime}\right)}\right)$, the wage covariance of brothers. The sample estimate of each moment and the value predicted by the factor model for each of the moments are reported in the second and third columns. The actual and fitted values are .0562 and .0548 in the case of the brothers' wage covariance. Columns 4 and 5 report the marginal contribution of the father's wage factor, $\mathrm{W}_{\mathrm{if}}$ and the mother's wage factor, $\mathrm{W}_{\mathrm{im}}$. In column 6 we report the total contribution of the parents' wage factors, which is the sum of 4 and 5 plus the contribution of the covariance $\operatorname{Cov}\left(\mathrm{W}_{\mathrm{if}} \mathrm{W}_{\mathrm{im}}\right)$ of their wage factors. The contribution of the sibling factor, $\omega_{i s}$, and the contribution of the idiosyncratic factor $\omega_{i b}$ or $\omega_{\text {ig }}$ are shown in the seventh and eighth columns. Columns 9 through 13 report the corresponding contributions of the various preference factors. The number in parentheses below each factor contribution is the fraction of the predicted value of the particular moment (column 3) that is due to the particular factor.

For example, the results in Table $2 \mathrm{a}$ (row 2) indicate that $\mathrm{W}_{\text {if }}$ is responsible for 26 percent of the covariance of brothers' wages and 11 percent of the variance of wages of young men. (row 3) The mother's wage contribution, $\mathrm{W}_{\mathrm{im}}$, is 14 percent of $\operatorname{Cov}\left(\mathrm{W}_{\mathrm{ib}(\mathrm{j})}, \mathrm{W}_{\mathrm{ib}\left(\mathrm{j}^{\prime}\right)}\right)$ and 6 percent of $\operatorname{Var}\left(W_{i b(j)}\right)$. The total contribution of the parents' wages-- the father's plus the mother's plus their covariance--is 54 percent of the covariance between brothers' wages, and 22 percent of the variance of young men's wages. The sibling wage factor accounts for 46 percent of the similarity between brothers and only 19 percent of the variance in the wages of young men. Fifty-nine percent of the young men's wage variance is due to the idiosyncratic wage factor. Given space limitations we limit discussion to the main results for wages, hours, and earnings. 


\section{III.1 Wages (Table 2a)}

What explains the variance of wages? The father's wage factor and mother's wage factor explain 11 percent and 6 percent of the variance of young men's wages. However, the total parents' contribution is 22 percent of the variance of young men's wages (rather than 17 percent) because the two parental factors have a positive covariance, The sibling wage factor and the idiosyncratic wage factor account for 19 percent and 59 percent, respectively. The wage variance decomposition is similar for young women. Sibling wage effects are a bit less important for young women and sister pairs than for young men and brother pairs, which reflects the fact that the sibling factor coefficient $\left(\mathrm{a}_{\mathrm{gs}}\right)$ in the young women's wage equation in Table 1 was estimated to be .831 while the young men's coefficient is 1 .

The decompositions of the covariances of the wages of parents and children are particularly interesting. The result in row 3 of Table $2 \mathrm{a}$ indicates that the father's factor, $\mathrm{w}_{\text {if }}$ explains 78 percent of the father-son wage covariance. The rest is attributed to the fact that the father's wage factor is positively correlated with the mother's wage factor, and the mother's wage factor has a direct effect on the wage of the son. ${ }^{22}$ The results for the father-daughter wage covariance are very similar, with $\mathrm{W}_{\text {if }}$ explaining 82 percent of the covariance (see row 7). Turning to the mother-son and mother-daughter covariances, we find that the mother's wage factor, $\mathrm{W}_{\mathrm{im}}$, accounts for only 67 percent of the wage covariance between mothers and sons and for 62 percent between mothers and daughters. The remainder is due to the fact that the mother's wage factor is positively correlated with the father's wage factor and the father's wage factor has a

\footnotetext{
22. To appreciate the size of the parents' wage covariance, note that the sample covariance of the wages of fathers and mothers (in row 12 of Table $2 a$ ) is .0532 , which is more than 25 percent of the variance of the fathers' wages (row 10) and almost half the variance of the mothers' wages (row 11).
} 
direct effect on the children's wages. ${ }^{23}$ These findings imply is that studies of intergenerational inequality that simply look at, say, the correlation between fathers and sons' wages or incomes overstate the direct effect of the father by attributing part of the mother's influence to the father.

Given the substantial literature on sibling correlations in income, it is also interesting to look at the covariance in sibling wages. The parents' total contribution to the wage covariance of brothers is .0298 or 54 percent of the total covariance of brothers' wages. Sibling wage factors account for 46 percent of the covariance in brothers' wages. The importance of the parents' wage factors and siblings' wage factors are similar for sister pairs and brother-sister pairs.

\section{III.2 Hours (Table 2b)}

In view of the relatively small wage elasticities for young men and young women found in Table 1, it is not surprising that parental wage factors play only a small role in the variances of hours of young men (zero percent) and young women (1 percent) and in the covariances of hours of siblings. ${ }^{24}$ The sibling wage factor also plays a relatively small role (in no case more than 5 percent) in these same moments. For brothers, the parental and sibling wage factors together explain only 3 percent of the variance in hours. For sisters, the parental wage factor explains 4 percent of the hours covariance and the sibling factor explains 3 percent. And for brother-sister pairs, the combined parents' and sibling wage effects explain 11 percent of the hours covariance.

The idiosyncratic components of wages also explain very little ( 1 percent) of the variation in the hours of young men and young women. For older men the wage factor explains only 3

\footnotetext{
23 One explanation for the larger role of the father's factor in the wages of both young men and young women is that the wage rate may be a less accurate measure of the human capital of mothers than of fathers because of the large role women play in productive activity outside of the labor market.

24. It should be pointed out the model slightly underestimates the hours covariance of brothers and substantially underestimates the hours covariance of sisters. The model overestimates the hours covariance between brothers and sisters. Compare columns 2 and 3 in the first, fifth, and ninth rows.
} 
percent of their hours variance (row 10, column 4) leaving 97 percent of hours variation explained by variation in their preferences. However, for mature women variation in the wage factor, $\mathrm{W}_{\mathrm{im}}$, explains 16 percent the variation in hours (row 11, column 5). This reflects the larger wage elasticity for mature women.

On the other hand, the parental and sibling hours preference factors make an important contribution to the covariance in the hours of siblings, but there are large differences in the parental influences for males and females. The fathers' preference factor, $U_{\text {if }}$ contributes 25 percent of the covariance in brothers' hours, but only 5 percent of sisters' hours. At the same time, mothers' preferences account for essentially none of the brothers' or brothers-sisters' hours covariance but 78 percent of sisters' hours covariance. In combination, the parental factors account for three times as much of the sisters' hours covariance than for the brothers'. The sibling preference factor explains 96 percent of the brother-sister hours covariance, 73 percent of the brothers', but only 20 percent of the sisters'.

The hours variances of young men and young women show a similar gender-specific pattern. Only the fathers' preferences matter for young men and mothers' preferences matter for young women. In both cases, the parental preference contribution to the hours variation is small, around 7 percent. The sibling factor $u_{i s}$ makes the same absolute contribution (.0044) to the variance of the hours of young women and of young men, but because young women have a much higher hours variance than young men (.1969 versus .0268$)$ this contribution is only 2 percent of the young women's total versus 17 percent for young men. A large part of the difference in the variance of hours of young women and young men comes from the idiosyncratic factor, which has a variance of .197 (or 89 percent) for young women and only .020 (or 76 percent) for young men. The gender specific pattern in the roles of the father's and mother's preferences in the variance 
decompositions reflects the gender-specific pattern of the coefficients in the preference equations shown in the top panel of Table 1.

\section{III.3 Earnings (Table 2c)}

Table $2 \mathrm{c}$ provides estimates of the relative importance of wage factors and hours preference factors for the variances and covariances of earnings. With respect to the variance of earnings of young men (row 2), the parental wage factors explain 19 percent, the sibling wage factor explains 16 percent and the idiosyncratic wage factor explains 50 percent of the variance. All together, 85 percent of the variance of earnings among young men is due to wage factors. The parental hours preferences contribute 1 percent of the variance in earnings. The sibling and the idiosyncratic hours preference factors explain 2 percent and 12 percent, respectively.

For young women, the relative importance of wage differences and preference differences is reversed (row 6). The parental, sibling and idiosyncratic wage factors contribute 11 percent, 7 percent and 26 percent, or a total of 44 percent, of the variance of $E_{i g}$. The parental, sibling, and idiosyncratic hours preference factors contribute 4 percent, 1 percent and 51 percent of the remaining variance in young women's earnings. For young women, the mother's hours preference factor explains 4 percent of the total variance and 19 percent of the sisters' earnings covariance.

(row 5) In contrast, the mother's contributions for young men and for brothers are essentially zero.

Overall about 50 percent of the covariation in siblings' earnings is due to parental wage factors and 40 percent to sibling wage factors. For brother and brother-sister pairs, parental preference factors are small relative to sibling factors, but for sister pairs mothers' preferences contribute 19 percent of the covariance in earnings. In light of the wage and hours results reported above, it is not surprising to find that 75 percent of the covariance in the earnings of 
fathers and sons is due to the father's wage factor, while only 4 percent is due to the father's preference factor. The covariances of the earnings of sons and mothers, and daughters and fathers are also dominated by the parental wage rather than preference factors. However, the mother's preference factor explains a relatively large 37 percent of the covariance of earnings between mothers and daughters (and zero percent between mothers and sons).

Finally, it is interesting to note that the variation in earnings of fathers is dominated by the wage factor, which explains 97 percent of the variance in row 10. For mothers (in row 11), the wage factor explains 71 percent of earnings. However, 29 percent the influence of the mother's wage factor on mother's earnings operates through the labor supply response to wages. ${ }^{25}$

\section{Conclusion}

In this paper we use a simple factor model to explore the sources of variation in wages, hours, and earnings and of family similarities in these variables. We estimate the model using matched intergenerational and intragenerational panel data on labor market outcomes. Our factor model explains most of the variation in the sample moments. The gender differences in the relative importance of work preferences and wage rates in the determination of work hours, and in the relative influence of fathers and mothers have some intuitive appeal. Furthermore, we obtain reasonable uncompensated labor supply elasticities of .056 for young men, .077 for older men, .184 for young women, and .445 for mature women.

Rather than provide a detailed restatement of the results, it may be helpful to return to questions posed in the introduction. Are the wage rates and work preferences of young men and

\footnotetext{
25. This fraction was calculated as the ratio of the indirect influence of wages on earnings, which operates through the labor supply response of hours to wages, to the sum of the direct effect of wages on earnings plus the indirect effect. From equation (4) the reader can verify this ratio is $\phi_{\mathrm{hm}} \beta_{1} /\left[\phi_{\mathrm{um}}+\phi_{\mathrm{hm}} \beta_{\mathrm{m}}\right]$, which equals 28 when the appropriate parameter valuesfrom Table 1 are substituted. For fathers, the labor response to wages accounts for 4 percent of the wage contribution to their earnings.
} 
young women influenced primarily by fathers, mothers, or by characteristics of the family environment that are unrelated to the wages and labor supply preferences of the parents? To what extent does the correlation between the labor market outcomes of fathers and sons arise because of a direct effect of the father's characteristics on the son, and to what extent do they arise because assortative mating selects the characteristics of the mother, which then directly influence the son's labor market outcome? First, we find that there are strong family similarities in work hours that run along gender lines. Second, these similarities are due primarily to intergenerational and sibling correlations in preferences rather than to labor supply responses to similarities in wages. A unit increase in the father's hours preference factor leads to .193 increase in the son's hours preferences, while a unit increase the mother's hours preference factor leads to .383 increase in daughter's hours preferences. Six percent of the total variance in hours of young men is associated with parental preference factors and 17 percent is associated with the sibling preference factor, for a total of 23 percent. This is an important result given that wage rates, nonlabor income, and observed personal characteristics in the typical labor supply model for men explain very little variance in hours. (See Pencavel (1986). While the evidence in Altonji and Dunn (1991) suggests that part of the correlation is due to family correlations in labor market constraints, our results imply that the role of the family in the formation of work preferences deserves detailed study. For young women only about 9 percent of the total variance is associated with parental plus sibling preference factors, with the remainder is claimed by an individual effect that is much larger for women than for men.

Third, are the wage rates of young men and young women influenced primarily by fathers or mothers? Fourth, how important common sibling characteristics that are unrelated to the wages and labor supply preferences of the parents? The answer to the third question is that the wages of both sons and daughters are quite responsive to the wage factors of fathers and mothers, 
with coefficients between .2 and .3 for our preferred specification. The father's wage explains a substantially larger fraction of the total variance in wage rates, in part because the variation of the father's wage factor is substantially larger (by about one-third) than the variation in the mother's wage factor. The answer to the fourth question is that the sibling wage factor and combined parents' factors explain roughly the same percentages ( 45 percent and 55 percent) of the covariance of the wages of sibling pairs, no matter what type of sibling pair (brother-brother, sister-sister, or brother-sister) is considered. The father's wage factor explains twice as much of the sibling wage covariances as the mother's.

Fifth, to what extent does the correlation between the labor market outcomes of fathers and sons arise because of a direct effect of the father's characteristics on the son, and to what extent do they arise because assortative mating selects the characteristics of the mother, which then directly influence the son's labor market outcome? We find that intergenerational correlations substantially overestimate the direct influence of fathers, and especially mothers, on wages. For example, that the covariance of the father's and mother's wages account for 22 percent of the covariance between father's and son's wages.

Our results for young men's earnings indicate that 85 percent of the variation is due to the wage factors and 15 percent to the hours preference factors; similarly, for older men the figures are 97 percent and 3 percent. On the other hand, the hours preference factors are very important for the earnings of young women (claiming 56 percent), although almost all of the effect is accounted for by the idiosyncratic preference factor. For the mothers, 71 percent of the earnings variance is due to the wage factor, and 29 percent to the hours preference factor. Consequently, our decompositions of the earnings variances differ by gender, and by age in the case of women. For all groups most of the effect of wages on earnings is direct rather than through a labor supply response. 
We have highlighted a number of limitations of our model and methodology that will require further research. First, it would be useful to generalize the labor supply function to allow for parental wage effects on the children's marginal utility of income. Second, it would be useful to estimate labor supply models that depend upon marital status and to incorporate cross substitution effects of the spouse's wage. Third, and perhaps most important, it is important to address the problem of non-participation in the labor market, although it is difficult to do so in a factor model such as ours. ${ }^{26}$

Our findings in Altonji and Dunn (1991) of strong covariances in wages, hours, and earnings between mothers and fathers and of substantial covariances in the earnings of "in-laws" suggests that it would be useful to extend the model to include equations relating the hours preference factors and wage factors of say, a young woman's husband to her wages and hours preferences, as well as to the wage and hours preferences of her siblings and parents. Such an extension would be quite difficult because would be necessary to treat the endogeneity of marriage. If one were to add a fertility equations for married and unmarried women, one would have a complete model of the intergenerational transmission of income, hours and wage.

Finally, while factor models are a very powerful way to summarize the basic relationships in the data, one would like to know what underlies the wage and hours preference factors, particularly given the evidence that family plays an important role in both. There are many multiple regression studies of wage formation, but little research has been done on the relationship between observed family characteristics and childhood experiences and work hours.

\footnotetext{
26. We think that this is important not so much because we are concerned about selection bias in estimation of the labor supply elasticities, but because exclusion of data points in which individuals work zero hours probably has serious effects on our measures of the hours variances and covariances and on our estimates of the variances and covariances of leisure preferences.
} 


\section{References}

Altonji, Joseph G., and Thomas A. Dunn. "Relationships among the Family Incomes and Labor Market Outcomes of Relatives." Research in Labor Economics, 12 (1991): 269-310.

Altonji, Joseph G., Fumio Hayashi and Laurence J. Kotlikoff. "The Effects of Income and Wealth on Time and Money Transfers between Parents and Children", unpublished paper (October 1992)

Altonji, Joseph G. and Lewis M. Segal, "Small Sample Bias in GMM Estimation of Covariance Structures" NBER Techical Working Paper Series (1994).

Becker, Gary S., and Nigel Tomes. "Human Capital and the Rise and Fall of Families." Journal of Labor Economics 4 No 3 Pt 2 (July 1986): S1- S39.

Behrman, Jere R. and Paul Taubman, "The Intergenerational Correlation between Children's Adult Earnings and Their Parents' Income: Results from the Michigan Panel Study of Income Dynamics." Review of Income and Wealth 36 No. 2 (June 1990): 115-127.

Behrman, Jere R. and Paul. Taubman, "Is Schooling "Mostly in the Genes"? Nature-Nurture Decomposition Using Data on Relative", Journal of Political Economy

Blakemore, Arthur and Stuart Low, "Sex Differences in Occupational Selection: The Case of College Majors." Review of Economics and Statistics 63: 1 (February 1981): 60-69.

Case, Anne C. and L.F. Katz, "The Company You Keep: The Effects of Family and Neighborhood on Disadvantaged Youths" NBER working paper No. 3705. (1991)

Corcoran, Mary, Roger Gordon, Deborah Laren, and Gary Solon. "Effects of Family and Community Background on Men's Economic Status." American Economic Review 80 (May 1990): 362-366.

Corcoran, Mary and Christopher Jencks. "The Effects of Family Background." In C. Jencks et al., Who Gets Ahead? New York: Basic Books, 1979.

Dunn, Thomas A., "The Distribution of Intergenerational Income Transfers Acros and Within Families", unpublished paper, Syracuse University (1993).

England, Paula, "The Failure of Human Capital Theory to Explain Occupational Sex Segregation." Journal of Human Resources 17 (Summer 1982): 358-370.

Griliches, Zvi. "Sibling Models and Data in Economics: Beginnings of a Survey." Journal of Political Economy 87 (October 1979): S37- S64.

Hauser, Robert M. and William H. Sewell. "Family Effects in Simple Models of Education, Occupational Status and Earnings: Findings from the Wisconsin and Kalamazoo Studies." Journal of Labor Economics 4 (July 1986): S83- S115. 
Jencks, Christopher and Susan E. Mayer. "The Social Consequences of Growing Up in a Poor Neighborhood: A Review." in Concentrated Urban Poverty in America by M. McGeary and L. Lynn (ed.) Washington D.C.: National Academy Press.

Joulfiain, David and Mark Wilhelm, "Inheritance and Labor Supply", forthcoming, Journal of Human Resources.

Killingsworth, Mark and James Heckman, "Labor Supply of Women" in Ashenfelter and Layard (eds.) Handbook of Labor Economics (1986).

Mincer, Jacob and Solomon Polachek, "Family Investments in Human Capital: Earnings of Women." The Economics of the Family, Journal of Political Economy 82 (Supplement 1974): 76- 108 .

Mroz, Thomas A. "The Sensitivity of an Empirical Model of Married Women's Hours of Work to Economic and Statistical Assumptions." Econometrica 55 (July 1987): 765- 799.

Pencavel, John H. "Labor Supply of Men: A Survey." In Handbook of Labor Economics Volume 1, edited by Orley Ashenfelter and Richard Layard. New York: Elsevier- North Holland, 1986.

Polachek, Solomon, "Sex Differences in College Major". Industrial and Labor Relations Review 31 (July 1978): 498-508.

Schoeni, Robert F. "Private Interhousehold Transfers of Money and Time: New Empirical Evidence", Labor and Population Program Working Paper, RAND Corporation, 93-26 (July 1993)

Solon, Gary. "Intergenerational Income Mobility in the United States." American Economic Review 82 No. 3 (June 1992): 371-392.

Solon, Gary, Mary Corcoran, Roger Gordon, and Deborah Laren. "A Longitudinal Analysis of Sibling Correlations." Journal of Human Resources, 26 (Summer 1991): 509-534

Zimmerman, David J. "Intergenerational Income Mobility in the United States", 82 No. 3 (June 1992): 409-429. 


\section{Appendix 1: Formula for the Variance and Covariance Estimators and the WLS weights}

Let $Y_{\mathrm{jk}(j) t}$ be the adjusted labor market outcome of an individual, where $\mathrm{i}$ denotes a set of related individuals, $\mathrm{k}$ is the type of individual (e.g., young man, young woman, older man, or mature woman) and $j$ is an index indicating the specific individual of type $k$ from family $i$. (The index $\mathrm{j}$ may exceed $\mathrm{l}$ when $\mathrm{k}$ refers to young men or young women and there is more than one young man or young woman from a given family.) The index $t$ is a time subscript. Then our method of moments estimator of the covariance of variable $\mathrm{Y}$ with variable $\mathrm{Z}$ for family pair of type $k, k^{\prime}$ is

$$
\begin{aligned}
& \operatorname{Cov}\left(\mathrm{Y}_{\mathrm{ik}}, \mathrm{Z}_{\mathrm{ik}}{ }^{\prime}\right)=\sum\left\{\sum \sum \sum \mathrm{Y}_{\mathrm{ik}(\mathrm{j}) \mathrm{t}} \mathrm{Z}_{\mathrm{ik} \mathrm{k}^{\prime}\left(\mathrm{j}^{\prime}\right) \mathrm{t}^{\prime}}\right\} / \mathrm{N}_{\mathrm{YZkk}^{\prime}} \\
& \text { i } \quad j \quad j^{\prime} t t^{\prime}
\end{aligned}
$$

When $k=k^{\prime}$, as is the case for brother pairs and for sister pairs, then the covariance estimator when $\mathrm{Z}=\mathrm{Y}$ is

$$
\operatorname{Cov}\left(Y_{i k(j)}, Z_{i k\left(j^{\prime}\right)}\right)=\sum_{i}\left\{\sum_{j} \sum_{j^{\prime} \geq j} \sum \sum_{t} t_{t^{\prime}} Y_{i k(j) t} Z_{i k\left(j^{\prime}\right) t^{\prime}}\right\} / N_{Y Y k k}
$$

When $\mathrm{Z} \neq \mathrm{Y}$ the covariance estimator is

$$
\operatorname{Cov}\left(Y_{i k(j)}, Z_{i k\left(j^{\prime}\right)}\right)=\sum_{i}\left\{\sum_{j} \sum_{j^{\prime} \neq j} \sum_{t} \sum_{t^{\prime}} Y_{i k(j) t} Z_{i k\left(j^{\prime}\right) t^{\prime}}\right\} / N_{Y Z k k}
$$

Our method of moments variance estimator for the variable $\mathrm{Y}$ for person type $k$ is

$$
\text { (15) } \operatorname{Var}\left(Y_{i k(j)}\right)=\sum_{i}\left\{\sum_{j} \sum_{t} \sum_{t^{\prime}>t+2} Y_{i k(j) t} Y_{i k(j) t^{\prime}}\right\} / N_{Y k}
$$

The method of moments covariance estimator for the variables $\mathrm{Y}$ and $\mathrm{Z}$

for person type $k$ is

$$
\operatorname{Cov}\left(Y_{i k(j)}, Z_{i k(j)}\right)=\sum_{i}\left\{\sum_{j} \sum_{t} \sum_{t^{\prime}>t+2} Y_{i k(j) t} Z_{i k(j) t^{\prime}}\right\} / N_{Y Z k} \quad t^{\prime}<t-2
$$


In the above equations $\mathrm{N}_{\mathrm{YZkk}}, \mathrm{N}_{\mathrm{YYkk}}, \mathrm{N}_{\mathrm{YZkk}}, \mathrm{N}_{\mathrm{Yk} \text {, and }} \mathrm{N}_{\mathrm{YZk}}$ are the number of terms in the sums taken in (12), (13), (14), (15), and (16) respectively.

The WLS weights are based on estimates of the variances of the sample moments. In estimating them one must take account of the fact that individual crossproducts that enter the sums in (12) through (16) are not independent within each family i. We account for this by expressing each sample covariance as the sum of the sums of individual crossproducts contributed by each family i. The sums for a particular family i are the terms in brackets in (12), (13), (14) and (15). The sums in brackets are independent across families under our assumptions, and (after dividing by the average number of crossproducts per family) have an expectation (taken across families) equal to the particular covariance. It is then easy to formulate a consistent estimator of the variance of the sample covariance. For example, consider the covariance estimator in (12). One may rewrite $\operatorname{Cov}\left(\mathrm{Y}_{\mathrm{ik}}, \mathrm{Z}_{\mathrm{ik}} \mathrm{k}^{\prime}\right)$ as

$\operatorname{Cov}\left(\mathrm{Y}_{\mathrm{ik}}, \mathrm{Z}_{\mathrm{ik}}\right)^{\prime}=\left[1 / \mathrm{I}_{\mathrm{Ykk}}\right] \sum_{\mathrm{i}} \mathrm{S}_{\mathrm{i}}$

where $\mathrm{S}_{\mathrm{i}}=\left\{\sum \sum \sum \sum \mathrm{Y}_{\mathrm{ik}(\mathrm{j}) \mathrm{t}} \mathrm{Z}_{\mathrm{ik}^{\prime}\left(\mathrm{j}^{\prime}\right) \mathrm{t}^{\prime}}\right\}\left(\mathrm{I}_{\mathrm{YZkk}} \mathrm{N}_{\mathrm{YZkk^{ \prime }}}\right)$ $\begin{array}{llll}j & j^{\prime} & t & t^{\prime}\end{array}$

and $\mathrm{I}_{\mathbf{Y Z k k}^{\prime}}$ is the number of different families contributing observations on variables $\mathrm{Y}$ and $\mathrm{Z}$ for persons of type $k$ and $k^{\prime}$. One may think of the $S_{i}$ as independent and identically distributed random variables drawn from a distribution over all families. The expectation of $S_{i}$ over this distribution is $\operatorname{Cov}\left(\mathrm{Y}_{\mathrm{ik}}, \mathrm{Z}_{\mathrm{ik}}\right)$. It follows that a consistent estimator of the sampling variance of $\operatorname{Cov}\left(\mathrm{Y}_{\mathrm{ik}}, \mathrm{Z}_{\mathrm{ik}} \mathbf{k}^{\prime}\right)$ is

$\operatorname{Var}\left[\left(\operatorname{Cov}\left(\mathrm{Y}_{\mathrm{ik}}, \mathrm{Z}_{\mathrm{ik}^{\prime}}\right)^{\prime}\right)=\sum_{\mathrm{i}}\left[\mathrm{S}_{\mathrm{i}}-\operatorname{Cov}\left(\mathrm{Y}_{\mathrm{ik}}, \mathrm{Z}_{\mathbf{i k}^{\prime}}\right)^{2}\right]^{2} \mathrm{I}_{\mathrm{YZk}^{\prime}}\right.$ 
Table 1

Wus Estimates of Preference, Hage, Hours, and sarnings Equations

Preference Equations (7):

$$
\begin{aligned}
& U_{i b}=\underset{(.072)}{.215} U_{i f}-\underset{(.035)}{.008} u_{i m}+\underset{i s}{ }+u_{i b} \\
& u_{i g}=\underset{(.195)}{-.178} u_{i f}+\underset{(.081)}{.368} u_{i m}+\underset{i s}{ }+u_{i g}
\end{aligned}
$$

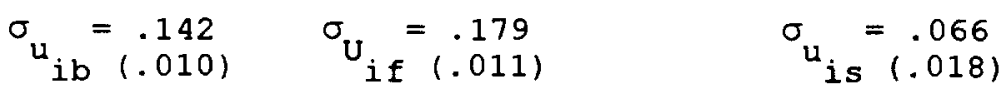

$$
\begin{aligned}
& \sigma_{u_{i g}(.017)}=\begin{array}{l}
.444 \\
U_{i m}(.016)
\end{array} \quad \operatorname{Cov}\left(U_{i f}, U_{i m}\right)=\frac{.016}{(.007)}
\end{aligned}
$$

Log Wage Equations (5):

$$
\begin{aligned}
& w_{i b}=\underset{(.033)}{.280} w_{i f}+\underset{(.037)}{.258} w_{i m}+\underset{i s}{ }+\omega_{i b} \\
& w_{i g}=\underset{(.041)}{.282} w_{i f}+\underset{(.040)}{.209} w_{i m}+\underset{(.183)}{.831} \omega_{i s}+\omega_{i g}
\end{aligned}
$$

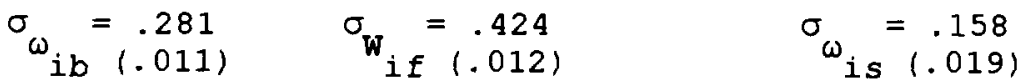

$$
\begin{aligned}
& \sigma_{\omega_{i g}(.011)}=.255 \quad \sigma_{W_{i m}}=.345 \quad \operatorname{Cov}\left(w_{i f}, w_{i m}\right)=\frac{.054}{(.005)}
\end{aligned}
$$

Log Hours Equations (2):

$$
\begin{aligned}
& \mathrm{H}_{\mathrm{ib}}=\underset{(.015)}{.056} \mathrm{w}_{\mathrm{ib}}+\mathrm{U}_{\mathrm{ib}} \\
& \mathrm{H}_{\mathrm{ig}}=\underset{(.045)}{(.045)} \mathrm{w}_{\mathrm{ig}}+\mathrm{U}_{\mathrm{ig}} \\
& \mathrm{H}_{\mathrm{if}}=\left(.077 \mathrm{w}_{\mathrm{if}}+(.027)\right. \\
& \mathrm{H}_{\mathrm{im}}=\left(.445 \mathrm{w}_{\mathrm{if}}+\right. \\
& (.043)
\end{aligned}
$$

Log Earnings Equations (3):

$$
\begin{aligned}
& E_{i b}=\underset{(.044)}{1.151} W_{i b}+\underset{(.161)}{1.172} \mathrm{H}_{i b} \\
& E_{i g}=\underset{(.081)}{1.089} \mathrm{w}_{\mathrm{ig}}+\underset{(.062)}{1.017} \mathrm{H}_{\mathrm{ig}} \\
& E_{i f}=\underset{(.066)}{1.120} \mathrm{w}_{\text {if }}+\underset{(.294)}{.551} \mathrm{H}_{\text {if }} \\
& E_{\text {im }}=\underset{(.101)}{1.072} \mathrm{~W}_{\mathrm{im}}+\underset{(.101)}{.933} \mathrm{H}_{\mathrm{im}}
\end{aligned}
$$

\section{Notes:}

1. Standard errors are reported in parentheses.

2. $\mathrm{R}^{2}=.99$ (unweighted moments). RMSE= .7847. Sum of Squared Errors= 35.10. The model was fitted to 90 sample moments, with 57 degrees of freedom. See Appendix 1 for a discussion of how the sample moments and weights were estimated.

3. The $p$ - value for the sSE based on a $x^{2} 57$ is .99. The use of this distribution as benchmark is valid only if the moments are independent, which is unlikely. 
Table 2a: Decomposition of Variances and Covariances

\begin{tabular}{|c|c|c|c|c|c|c|c|c|c|c|c|c|}
\hline \multirow{3}{*}{ Moment } & \multirow{3}{*}{$\begin{array}{l}\text { Sample } \\
\text { Estimate } 1\end{array}$} & \multirow{3}{*}{$\begin{array}{l}\text { Factor Model } \\
\text { Prediction }\end{array}$} & \multicolumn{10}{|c|}{ Source of Variance } \\
\hline & & & \multicolumn{5}{|c|}{ Wage Factors } & \multicolumn{5}{|c|}{ Preference Factors } \\
\hline & & & $\begin{array}{c}\text { Father } \\
W_{1 f}\end{array}$ & $\begin{array}{l}\text { Mother } \\
w_{\text {im }}\end{array}$ & $\begin{array}{c}\text { Total Parents } \\
W_{1 f}+W_{1 m}+\operatorname{Cov}\left(W_{f}, W_{m}\right)\end{array}$ & $\begin{array}{l}\text { sibling } \\
u_{\text {is }}\end{array}$ & $\begin{array}{l}\text { Individual } \\
w_{1 \mathrm{~b}} \text { or } w_{1 \mathrm{~g}}\end{array}$ & $\begin{array}{c}\text { Father } \\
u_{1 f}\end{array}$ & $\begin{array}{l}\text { Mother } \\
\mathrm{U}_{\text {im }}\end{array}$ & $\begin{array}{c}\text { Total Parents } \\
U_{1 f}+U_{i m}+\operatorname{Cov}\left(U_{f}, U_{m}\right)\end{array}$ & $\begin{array}{c}\text { sibling } \\
u_{\text {is }}\end{array}$ & $\begin{array}{l}\text { Individual } \\
u_{1 b} \text { or } u_{18}\end{array}$ \\
\hline $\operatorname{Cov}\left(W_{b}, W_{b},\right)$ & .0562 & .0548 & $\begin{array}{r}.014124 \\
(.26)\end{array}$ & $\begin{array}{r}.007918 \\
(.14)\end{array}$ & $\begin{array}{r}.029800 \\
(.54)\end{array}$ & $\begin{array}{r}.024967 \\
(.46)\end{array}$ & -- & & & & & \\
\hline $\operatorname{Cov}\left(W_{b}, W_{b}\right)$ & .1351 & .1337 & $\begin{array}{r}.014124 \\
(.11)\end{array}$ & $\begin{array}{r}.007918 \\
(.06)\end{array}$ & $\begin{array}{r}.029800 \\
(.22)\end{array}$ & $\begin{array}{r}.024967 \\
(.19)\end{array}$ & $\begin{array}{r}.078888 \\
(.59)\end{array}$ & & & & & \\
\hline $\operatorname{Cov}\left(W_{b}, W_{f}\right)$ & .0670 & .0642 & $\begin{array}{r}.050378 \\
(.78)\end{array}$ & -- & $\begin{array}{r}.064213 \\
(1.00)\end{array}$ & -- & -- & & & & & \\
\hline $\operatorname{Cov}\left(W_{b}, W_{m}\right)$ & .0454 & .0458 & -- & $\begin{array}{r}.030714 \\
(.67)\end{array}$ & $\begin{array}{r}.045761 \\
(1.00)\end{array}$ & -- & -- & & & & & \\
\hline $\operatorname{Cov}\left(W_{B}, W_{B},\right)$ & .0421 & .0430 & $\begin{array}{r}.014270 \\
(.33)\end{array}$ & $\begin{array}{r}.005179 \\
(.12)\end{array}$ & $\begin{array}{r}.025756 \\
(.60)\end{array}$ & $\begin{array}{r}.017221 \\
(.40)\end{array}$ & -- & & & & & \\
\hline $\operatorname{Cov}\left(W_{B}, W_{8}\right)$ & .1071 & .1081 & $\begin{array}{r}.014270 \\
(.13)\end{array}$ & $\begin{array}{r}.005179 \\
(.05)\end{array}$ & $\begin{array}{r}.025756 \\
(.24)\end{array}$ & $\begin{array}{r}.017221 \\
(.16)\end{array}$ & $\begin{array}{r}.065127 \\
(.60)\end{array}$ & & & & & \\
\hline $\operatorname{Cov}\left(W_{B} \cdot W_{f}\right)$ & .0545 & .0618 & $\begin{array}{r}.050636 \\
(.82)\end{array}$ & $-\cdot$ & $\begin{array}{r}.061827 \\
(1,00)\end{array}$ & $\cdots$ & -- & & & & & \\
\hline $\operatorname{Cov}\left(W_{B}, W_{m}\right)$ & .0398 & .0400 & -- & $\begin{array}{r}.024841 \\
(.62)\end{array}$ & $\begin{array}{r}.039966 \\
(1.00)\end{array}$ & -- & -- & & & & & \\
\hline $\operatorname{Cov}\left(W_{B}, w_{b}\right)$ & .0498 & .0484 & $\begin{array}{r}.014197 \\
(.29)\end{array}$ & $\begin{array}{r}.006404 \\
(.13)\end{array}$ & $\begin{array}{r}.027637 \\
(.57)\end{array}$ & $\begin{array}{c}.020735 \\
(.43)\end{array}$ & -- & & & & & \\
\hline $\operatorname{Cov}\left(W_{f}, W_{f}\right)$ & .1957 & .1797 & $\begin{array}{r}.179683 \\
(1.00)\end{array}$ & $-\cdot$ & -- & -- & -- & & & & & \\
\hline $\operatorname{Cov}\left(W_{m}, W_{m}\right)$ & .1196 & .1191 & -- & $\begin{array}{r}119142 \\
(1.00)\end{array}$ & -- & -- & -- & & & & & \\
\hline $\operatorname{Cov}\left(W_{f}, W_{m}\right)$ & .0532 & .0537 & -- & -- & $\begin{array}{r}.053670 \\
(1.00)\end{array}$ & -- & -- & & & & & \\
\hline
\end{tabular}

1 Semple estimates of moments are dram from Appendix Tables A2. Note that covariances of hours and wages, hours and carnings, and wages and earnings for the various family member pairs were also predicted by the factor model in Table 1 , but are not reported here. factors.

Note: Numbers in parentheses are the fractions of the factor model prediction attributable to the particular 
Table 2b: Decomposition of Variances and Covariances--Continued

\begin{tabular}{|c|c|c|c|c|c|c|c|c|c|c|c|c|}
\hline \multirow[b]{3}{*}{ Moment } & \multirow{3}{*}{$\begin{array}{l}\text { Sample } \\
\text { Estimate }\end{array}$} & \multirow{3}{*}{$\begin{array}{l}\text { Factor Model } \\
\text { Prediction }\end{array}$} & \multirow{2}{*}{\multicolumn{5}{|c|}{ Wage Factors }} & \multicolumn{5}{|l|}{ Variance } \\
\hline & & & & & & & & & & Preference Facto & tors & \\
\hline & & & $\begin{array}{c}\text { Father } \\
W_{1 f}\end{array}$ & \multirow{2}{*}{$\begin{array}{c}\begin{array}{c}\text { Mother } \\
w_{\text {im }}\end{array} \\
\begin{array}{c}.000025 \\
(.00)\end{array}\end{array}$} & $\begin{array}{c}\text { Total Parents } \\
W_{1 f}{ }^{+W_{1 m}}+\operatorname{Cov}\left(W_{f}, W_{m}\right)\end{array}$ & $\begin{array}{l}\text { Sibling } \\
w_{\text {is }}\end{array}$ & $\begin{array}{l}\text { Individual } \\
w_{i_{b}} \text { or } w_{i_{B}}\end{array}$ & $\begin{array}{c}\text { Father } \\
u_{1 f}\end{array}$ & $\begin{array}{l}\text { Mother } \\
U_{\text {im }}\end{array}$ & $\begin{array}{c}\text { Total Parents } \\
\mathrm{U}_{1 \mathrm{f}}+\mathrm{U}_{\mathrm{im}}+\operatorname{Cov}\left(\mathrm{U}_{\mathrm{f}}, \mathrm{U}_{\mathrm{m}}\right)\end{array}$ & $\begin{array}{c}\text { sibling } \\
u_{\text {is }}\end{array}$ & $\begin{array}{l}\text { Individual } \\
u_{1 b} \text { or } u_{18}\end{array}$ \\
\hline $\left.\operatorname{Cov}\left(B_{b}, H_{b}\right)^{\circ}\right)$ & .0091 & .0060 & $\begin{array}{c}.000045 \\
(.01)\end{array}$ & & $\begin{array}{r}.000094 \\
(.02)\end{array}$ & $\begin{array}{c}.000079 \\
(.01)\end{array}$ & -- & $\begin{array}{r}.001484 \\
(.25)\end{array}$ & $\begin{array}{c}.000009 \\
(.00)\end{array}$ & $\begin{array}{c}.001435 \\
(.24)\end{array}$ & $\begin{array}{r}.004410 \\
(.73)\end{array}$ & -- \\
\hline $\operatorname{Cov}\left(B_{b} \cdot B_{b}\right)$ & .0268 & .0264 & $\begin{array}{r}.000045 \\
(.00)\end{array}$ & $\begin{array}{r}.000025 \\
(.00)\end{array}$ & $\begin{array}{r}.000094 \\
(.00)\end{array}$ & $\begin{array}{r}.000079 \\
(.00)\end{array}$ & $\begin{array}{r}.000249 \\
(.01)\end{array}$ & $\begin{array}{r}.001484 \\
(.06)\end{array}$ & $\begin{array}{r}.000009 \\
(.00)\end{array}$ & $\begin{array}{r}.001435 \\
(.06)\end{array}$ & $\begin{array}{r}.004410 \\
(.17)\end{array}$ & $\begin{array}{r}.020121 \\
(.76)\end{array}$ \\
\hline $\operatorname{Cov}\left(B_{b}, B_{f}\right)$ & .0069 & .0070 & $\begin{array}{c}.000219 \\
(.03)\end{array}$ & -- & $\begin{array}{c}.000279 \\
(.04)\end{array}$ & -- & -- & $\begin{array}{r}.006893 \\
(.98)\end{array}$ & -- & $\begin{array}{c}.006759 \\
(.86)\end{array}$ & -- & -- \\
\hline $\operatorname{Cov}\left(B_{b}, B_{m}\right)$ & .0044 & .0036 & -- & $\begin{array}{r}.000767 \\
(.21)\end{array}$ & $\begin{array}{r}.001143 \\
(.32)\end{array}$ & -- & -- & -- & $\begin{array}{r}-.001027 \\
(-.29)\end{array}$ & $\begin{array}{c}.002443 \\
(.68)\end{array}$ & -- & -- \\
\hline $\operatorname{Cov}\left(B_{8}, B_{8}\right)$ & .0542 & .0215 & $\begin{array}{r}.000482 \\
(.02)\end{array}$ & $\begin{array}{r}.000175 \\
(.01)\end{array}$ & $\begin{array}{r}.000870 \\
(.04)\end{array}$ & $\begin{array}{r}.000581 \\
(.03)\end{array}$ & -- & $\begin{array}{r}.001009 \\
(.05)\end{array}$ & $\begin{array}{r}.016731 \\
(.78)\end{array}$ & $\begin{array}{r}.015634 \\
(.73)\end{array}$ & $\begin{array}{r}.004410 \\
(.20)\end{array}$ & -- \\
\hline $\operatorname{Cov}\left(H_{B}, B_{B}\right)$ & .1969 & .2210 & $\begin{array}{c}.000482 \\
(.00)\end{array}$ & $\begin{array}{r}.000175 \\
(.00)\end{array}$ & $\begin{array}{r}.000870 \\
(.01)\end{array}$ & $\begin{array}{r}.000581 \\
(.00)\end{array}$ & $\begin{array}{c}.002199 \\
(.01)\end{array}$ & $\begin{array}{r}.001009 \\
(.00)\end{array}$ & $\begin{array}{r}.016731 \\
(.08)\end{array}$ & $\begin{array}{r}.015634 \\
(.07)\end{array}$ & $\begin{array}{r}.004410 \\
(.02)\end{array}$ & $\begin{array}{r}.197296 \\
(.89)\end{array}$ \\
\hline $\operatorname{Cov}\left(\mathrm{H}_{8}, \mathrm{~B}_{\mathrm{f}}\right)$ & .0001 & .0011 & $\begin{array}{r}.000719 \\
(.64)\end{array}$ & -- & $\begin{array}{r}.000877 \\
(.78)\end{array}$ & - & -- & $\begin{array}{c}-.005683 \\
(-5.04)\end{array}$ & -- & $\begin{array}{r}.000251 \\
(.22)\end{array}$ & -- & -- \\
\hline $\operatorname{Cov}\left(\mathrm{H}_{\mathbf{8}}, \mathrm{B}_{\mathrm{m}}\right)$ & .0408 & .0459 & -- & $\begin{array}{r}.002029 \\
(.04)\end{array}$ & $\begin{array}{r}.003265 \\
(.07)\end{array}$ & -- & -- & $\cdots$ & $\begin{array}{r}.045450 \\
(.99)\end{array}$ & $\begin{array}{r}.042588 \\
(.93)\end{array}$ & -- & -- \\
\hline $\operatorname{Cov}\left(\mathrm{H}_{8}, \mathrm{~B}_{\mathrm{b}}\right)$ & .0008 & .0046 & $\begin{array}{r}.000147 \\
(.03)\end{array}$ & $\begin{array}{r}.000066 \\
(.01)\end{array}$ & $\begin{array}{c}.000285 \\
(.06)\end{array}$ & $\begin{array}{r}.000214 \\
(.05)\end{array}$ & -- & $\begin{array}{c}-.001223 \\
(-.27)\end{array}$ & $\begin{array}{c}-.000378 \\
(-.08)\end{array}$ & $\begin{array}{l}-.000300 \\
(-.07)\end{array}$ & $\begin{array}{r}.004410 \\
(.96)\end{array}$ & -- \\
\hline $\operatorname{Cov}\left(B_{f}, B_{f}\right)$ & .0333 & .0331 & $\begin{array}{r}.001072 \\
(.03)\end{array}$ & - & -- & -- & -- & $\begin{array}{r}.032020 \\
(.97)\end{array}$ & -- & -- & -- & -- \\
\hline $\operatorname{Cov}\left(B_{m}, H_{m}\right)$ & .1492 & .1470 & -- & $\begin{array}{r}.023543 \\
(.16)\end{array}$ & -- & -- & -- & -- & $\begin{array}{r}.123461 \\
(.84)\end{array}$ & -- & -- & -- \\
\hline $\operatorname{Cov}\left(B_{f}, H_{m}\right)$ & .0183 & .0180 & - & -- & $\begin{array}{r}.001843 \\
(.10)\end{array}$ & -- & -- & -- & - & $\begin{array}{r}.016120 \\
(.90)\end{array}$ & -- & -- \\
\hline
\end{tabular}

1 Sample estimates of moments are drawn from Appendix Table A2. Note that covariances of hours and wages, hours and earnings, and wages. and earnings for the various family member pairs were also predicted by the factor model in Table 1 ,

but are not reported here. 
Table 2c: Decomposition of Variances and Covariances--Continued

\begin{tabular}{|c|c|c|c|c|c|c|c|c|c|c|c|c|}
\hline \multirow{3}{*}{ Moment } & \multirow{3}{*}{$\begin{array}{l}\text { Sample } \\
\text { Estimate }\end{array}$} & \multirow{3}{*}{$\begin{array}{l}\text { Factor Model } \\
\text { Prediction }\end{array}$} & \multicolumn{10}{|c|}{ Source of Variance } \\
\hline & & & \multicolumn{5}{|c|}{ Wage Factors } & \multicolumn{5}{|c|}{ Proference Factors } \\
\hline & & & $\begin{array}{c}\text { Father } \\
W_{1 f}\end{array}$ & $\begin{array}{l}\text { Mother } \\
W_{1 m}\end{array}$ & $\begin{array}{c}\text { Total Parents } \\
W_{i f}+W_{i m}+\operatorname{Cov}\left(W_{f}, w_{m}\right)\end{array}$ & $\begin{array}{l}\text { Sibling } \\
\omega_{1 \mathrm{~s}}\end{array}$ & $\begin{array}{l}\text { Individual } \\
w_{i b} \text { or } w_{i B}\end{array}$ & $\begin{array}{c}\text { Father } \\
\mathrm{U}_{1 \mathrm{f}}\end{array}$ & $\begin{array}{l}\text { Mother } \\
U_{1 m}\end{array}$ & $\begin{array}{c}\text { Total Parents } \\
U_{1 f}+U_{\text {im }}+\operatorname{Cov}\left(U_{f}, U_{m}\right)\end{array}$ & $\begin{array}{c}\text { Stbling } \\
u_{\text {is }}\end{array}$ & $\begin{array}{l}\text { Individual } \\
u_{i b} \text { or } u_{i g}\end{array}$ \\
\hline $\operatorname{Cov}\left(E_{b}, E_{b},\right)$ & .0853 & .0891 & $\begin{array}{r}.020919 \\
(.23)\end{array}$ & $\begin{array}{r}.011726 \\
(.13)\end{array}$ & $\begin{array}{r}.044135 \\
(.50)\end{array}$ & $\begin{array}{r}.036977 \\
(.41)\end{array}$ & -- & $\begin{array}{r}.002037 \\
(.02)\end{array}$ & $\begin{array}{r}.000012 \\
(.00)\end{array}$ & $\begin{array}{r}.001970 \\
(.02)\end{array}$ & $\begin{array}{r}.006056 \\
(.07)\end{array}$ & -- \\
\hline $\operatorname{Cov}\left(E_{b}, E_{b}\right)$ & .2430 & .2336 & $\begin{array}{r}.020919 \\
(.09)\end{array}$ & $\begin{array}{r}.011726 \\
(.05)\end{array}$ & $\begin{array}{r}.044135 \\
(.19)\end{array}$ & $\begin{array}{r}.036977 \\
(.16)\end{array}$ & $\begin{array}{r}.116836 \\
(.50)\end{array}$ & $\begin{array}{r}.002037 \\
(.01)\end{array}$ & $\begin{array}{r}.000012 \\
(.00)\end{array}$ & $\begin{array}{r}.001970 \\
(.01)\end{array}$ & $\begin{array}{r}.006056 \\
(.02)\end{array}$ & $\begin{array}{r}.027628 \\
(.12)\end{array}$ \\
\hline $\operatorname{Cov}\left(E_{b}, E_{f}\right)$ & .1061 & .1014 & $\begin{array}{r}.076115 \\
(.75)\end{array}$ & - & $\begin{array}{r}.097019 \\
(.96)\end{array}$ & -- & -- & $\begin{array}{c}.004448 \\
(.04)\end{array}$ & - & $\begin{array}{r}.004362 \\
(.04)\end{array}$ & -- & - \\
\hline $\operatorname{Cov}\left(E_{b}, E_{m}\right)$ & .0863 & .0855 & -- & $\begin{array}{r}.055573 \\
(.65)\end{array}$ & $\begin{array}{r}.082800 \\
(.97)\end{array}$ & -- & - & -- & $\begin{array}{r}-.001122 \\
(-.01)\end{array}$ & $\begin{array}{c}.002670 \\
(.03)\end{array}$ & -- & -- \\
\hline $\operatorname{Cov}\left(E_{B}, E_{B},\right)$ & .0970 & .0907 & $\begin{array}{r}.023241 \\
(.26)\end{array}$ & $\begin{array}{r}.008435 \\
(.09)\end{array}$ & $\begin{array}{r}.041948 \\
(.46)\end{array}$ & $\begin{array}{r}.028047 \\
(.31)\end{array}$ & -- & $\begin{array}{r}.001043 \\
(.01)\end{array}$ & $\begin{array}{r}.017305 \\
(.19)\end{array}$ & $\begin{array}{r}.016169 \\
(.18)\end{array}$ & $\begin{array}{r}.004561 \\
(.05)\end{array}$ & $\cdots$ \\
\hline $\operatorname{Cov}\left(E_{B}, E_{B}\right)$ & .3764 & .4009 & $\begin{array}{r}.023241 \\
(.06)\end{array}$ & $\begin{array}{r}.008435 \\
(.02)\end{array}$ & $\begin{array}{r}.041948 \\
(.11)\end{array}$ & $\begin{array}{r}.028047 \\
(.07)\end{array}$ & $\begin{array}{r}.106070 \\
(.26)\end{array}$ & $\begin{array}{r}.001043 \\
(.00)\end{array}$ & $\begin{array}{r}.017305 \\
(.04)\end{array}$ & $\begin{array}{r}.016169 \\
(.04)\end{array}$ & $\begin{array}{r}.004561 \\
(.01)\end{array}$ & $\begin{array}{r}.204057 \\
(.51)\end{array}$ \\
\hline $\operatorname{Cov}\left(E_{B}, E_{f}\right)$ & .1329 & .0981 & $\begin{array}{r}.080228 \\
(.82)\end{array}$ & -- & $\begin{array}{r}.097958 \\
(1.00)\end{array}$ & -- & - & -- & $\begin{array}{c}-.003183 \\
(-.03)\end{array}$ & $\begin{array}{r}.000140 \\
(.00)\end{array}$ & -- & -- \\
\hline $\operatorname{Cov}\left(E_{g}, E_{m}\right)$ & .1027 & .1162 & -- & $\begin{array}{r}.047134 \\
(.41)\end{array}$ & $\begin{array}{r}.075833 \\
(.65)\end{array}$ & -- & -- & -- & $\begin{array}{r}.043103 \\
(.37)\end{array}$ & $\begin{array}{r}.040389 \\
(.35)\end{array}$ & -- & -- \\
\hline $\operatorname{Cov}\left(E_{g}, E_{b}\right)$ & .0881 & .0800 & $\begin{array}{r}.022049 \\
(.28)\end{array}$ & $\begin{array}{r}.009946 \\
(.12)\end{array}$ & $\begin{array}{r}.042923 \\
(.54)\end{array}$ & $\begin{array}{r}.032204 \\
(.40)\end{array}$ & -- & $\begin{array}{c}-.001458 \\
(-.02)\end{array}$ & $\begin{array}{c}-.000450 \\
(-.01)\end{array}$ & $\begin{array}{c}-.000358 \\
(-.00)\end{array}$ & $\begin{array}{r}.005256 \\
(.06)\end{array}$ & -- \\
\hline $\operatorname{Cov}\left(E_{f}, E_{f}\right)$ & .2992 & .2867 & $\begin{array}{r}.276951 \\
(.97)\end{array}$ & -- & - & -- & -- & $\begin{array}{r}.009712 \\
(.03)\end{array}$ & -- & - & -- & -- \\
\hline $\operatorname{Cov}\left(E_{m}, E_{m}\right)$ & .3761 & .3707 & -- & $\begin{array}{r}.263371 \\
(.71)\end{array}$ & - & -- & -- & -- & $\begin{array}{r}.107361 \\
(.29)\end{array}$ & -- & -- & -- \\
\hline $\operatorname{Cov}\left(E_{f}, E_{m}\right)$ & .1142 & .1073 & -- & -- & $\begin{array}{r}.099067 \\
(.92)\end{array}$ & -- & -- & -- & -- & $\begin{array}{r}.008279 \\
(.08)\end{array}$ & -- & -- \\
\hline
\end{tabular}

1 Sample estimates of moments are drawn from Appendix Table A2. Note that covariances of hours and wages, hours and earnings, and wages and earnings for the various family member pairs were also predicted by the factor model in Table 1 , but are not reported here.

Numbers in parentheses are the fractions of the factor model prediction attributable to the particular 


\begin{tabular}{|c|c|c|c|c|c|c|c|}
\hline Variable & Mean & $\begin{array}{l}\text { Std } \\
\text { Dev }\end{array}$ & 08 & 258 & $\begin{array}{c}\text { antil } \\
508\end{array}$ & 758 & 1008 \\
\hline \multicolumn{8}{|l|}{ Young Men } \\
\hline $\begin{array}{l}\text { log hourly wage } \\
\text { log annual hours } \\
\text { log earnings } \\
\text { age } \\
\text { education } \\
\text { black }\end{array}$ & $\begin{array}{r}1.15 \\
7.61 \\
8.75 \\
29.89 \\
12.56 \\
0.23\end{array}$ & $\begin{array}{l}0.46 \\
0.34 \\
0.61 \\
4.25 \\
2.75 \\
--\end{array}$ & $\begin{array}{r}-0.89 \\
1.38 \\
4.62 \\
24.0 \\
0.0 \\
--\end{array}$ & $\begin{array}{l}0.85 \\
7.51 \\
8.48 \\
26.0 \\
12.0 \\
--\end{array}$ & $\begin{array}{l}1.18 \\
7.64 \\
8.85 \\
29.0 \\
12.0 \\
--\end{array}$ & $\begin{array}{l}1.45 \\
7.76 \\
9.13 \\
33.0 \\
14.0 \\
--\end{array}$ & $\begin{array}{r}5.22 \\
8.51 \\
10.67 \\
39.0 \\
18.0 \\
--\end{array}$ \\
\hline \multicolumn{8}{|l|}{ Young Women } \\
\hline $\begin{array}{l}\text { log hourly wage } \\
\text { log annual hours } \\
\text { log earnings } \\
\text { age } \\
\text { education } \\
\text { black }\end{array}$ & $\begin{array}{r}0.67 \\
7.19 \\
7.86 \\
29.29 \\
12.37 \\
0.30\end{array}$ & $\begin{array}{l}0.43 \\
0.81 \\
0.92 \\
3.90 \\
2.19 \\
--\end{array}$ & $\begin{array}{r}-0.91 \\
2.77 \\
4.61 \\
24.0 \\
0.0 \\
--\end{array}$ & $\begin{array}{l}0.38 \\
7.02 \\
7.47 \\
26.0 \\
12.0 \\
--\end{array}$ & $\begin{array}{l}0.66 \\
7.58 \\
8.10 \\
29.0 \\
12.0 \\
--\end{array}$ & $\begin{array}{l}0.95 \\
7.64 \\
8.48 \\
32.0 \\
13.0 \\
--\end{array}$ & $\begin{array}{r}3.19 \\
8.51 \\
10.34 \\
38.0 \\
18.0 \\
--\end{array}$ \\
\hline \multicolumn{8}{|l|}{ Older Men } \\
\hline $\begin{array}{l}\text { log hourly wage } \\
\text { log annual hours } \\
\text { log earnings } \\
\text { age } \\
\text { education } \\
\text { black }\end{array}$ & $\begin{array}{r}1.18 \\
7.65 \\
8.85 \\
52.62 \\
10.41 \\
0.24\end{array}$ & $\begin{array}{l}0.50 \\
0.30 \\
0.61 \\
4.14 \\
3.80 \\
--\end{array}$ & $\begin{array}{r}-0.82 \\
4.38 \\
5.03 \\
45.0 \\
0.0 \\
--\end{array}$ & $\begin{array}{l}0.90 \\
7.64 \\
8.58 \\
49.0 \\
8.0 \\
--\end{array}$ & $\begin{array}{l}1.20 \\
7.64 \\
8.92 \\
52.0 \\
11.0 \\
--\end{array}$ & $\begin{array}{l}1.48 \\
7.76 \\
9.22 \\
56.0 \\
12.0 \\
--\end{array}$ & $\begin{array}{r}3.39 \\
8.45 \\
10.15 \\
60.0 \\
18.0 \\
-\end{array}$ \\
\hline \multicolumn{8}{|l|}{ Mature Women } \\
\hline $\begin{array}{l}\text { log hourly wage } \\
\text { log annual hours } \\
\text { log earnings } \\
\text { age } \\
\text { education } \\
\text { black }\end{array}$ & $\begin{array}{r}0.59 \\
7.28 \\
7.93 \\
47.85 \\
10.81 \\
0.35\end{array}$ & $\begin{array}{l}0.43 \\
0.68 \\
0.79 \\
6.08 \\
2.60 \\
--\end{array}$ & $\begin{array}{r}-0.92 \\
1.10 \\
4.62 \\
31.0 \\
1.0 \\
--\end{array}$ & $\begin{array}{c}0.31 \\
7.15 \\
7.55 \\
43.0 \\
9.0 \\
--\end{array}$ & $\begin{array}{c}0.58 \\
7.58 \\
8.10 \\
48.0 \\
12.0 \\
--\end{array}$ & $\begin{array}{c}0.87 \\
7.64 \\
8.45 \\
52.0 \\
12.0 \\
--\end{array}$ & $\begin{array}{r}3.72 \\
8.38 \\
10.29 \\
60.0 \\
18.0 \\
--\end{array}$ \\
\hline
\end{tabular}

\section{Notes:}

1. Wages and earnings are in 1967 dollars.

2. The data used to calculate these statistics are the same used to generate the covariances in Table A2. 
Table A2 Family Covariances, (Correlations) and [Sample Sizes] among the Permanent Components of Log Real Earnings, Log Real Wage Rates, and Log Annual Hours.

\begin{tabular}{|c|c|c|c|c|c|c|}
\hline & $\begin{array}{l}\text { father's } \\
\text { earnings }\end{array}$ & $\begin{array}{l}\text { father's } \\
\text { wages }\end{array}$ & $\begin{array}{l}\text { father's } \\
\text { hours }\end{array}$ & $\begin{array}{l}\text { mother's } \\
\text { earnings }\end{array}$ & $\begin{array}{l}\text { mother's } \\
\text { wages }\end{array}$ & $\begin{array}{l}\text { mother's } \\
\text { hours }\end{array}$ \\
\hline $\begin{array}{l}\text { father's } \\
\text { earnings }\end{array}$ & $\begin{array}{l}.2992 \\
(1.00) \\
{[6417]}\end{array}$ & $\begin{array}{l}.1999 \\
(.8261) \\
{[4610]}\end{array}$ & $\begin{array}{l}.0365 \\
(.3659) \\
{[6109]}\end{array}$ & $\begin{array}{l}.1142 \\
(.3404) \\
{[5313]}\end{array}$ & $\begin{array}{l}.0688 \\
(.3637) \\
{[6411]}\end{array}$ & $\begin{array}{l}.0312 \\
(.1477) \\
{[4320]}\end{array}$ \\
\hline $\begin{array}{l}\text { father's } \\
\text { wages }\end{array}$ & & $\begin{array}{l}.1957 \\
(1.0) \\
{[3487]}\end{array}$ & $\begin{array}{l}.0002 \\
(.0025) \\
{[2417]}\end{array}$ & $\begin{array}{l}.0738 \\
(.2720) \\
{[4298]}\end{array}$ & $\begin{array}{l}.0532 \\
(.3477) \\
{[5227]}\end{array}$ & $\begin{array}{l}.0161 \\
(.0942) \\
{[3511]}\end{array}$ \\
\hline $\begin{array}{l}\text { father's } \\
\text { hours }\end{array}$ & & & $\begin{array}{l}.0333 \\
(1.0) \\
{[3485]}\end{array}$ & $\begin{array}{l}.0143 \\
(.1279) \\
{[4700]}\end{array}$ & $\begin{array}{l}.0115 \\
(.1824) \\
{[5690]}\end{array}$ & $\begin{array}{l}.0183 \\
(.2598) \\
{[3907]}\end{array}$ \\
\hline $\begin{array}{l}\text { mother's } \\
\text { earnings }\end{array}$ & & & & $\begin{array}{l}.3761 \\
(1.0) \\
{[18284]}\end{array}$ & $\begin{array}{l}.1753 \\
(.8265) \\
{[17645]}\end{array}$ & $\begin{array}{l}.1906 \\
(.8046) \\
{[11893]}\end{array}$ \\
\hline $\begin{array}{l}\text { mother's } \\
\text { wages }\end{array}$ & & & & & $\begin{array}{l}.1196 \\
(1.0) \\
{[27304]}\end{array}$ & $\begin{array}{l}.0521 \\
(.3900) \\
{[17564]}\end{array}$ \\
\hline $\begin{array}{l}\text { mother's } \\
\text { hours }\end{array}$ & & & & & & $\begin{array}{l}.1492 \\
(1.0) \\
{[11593]}\end{array}$ \\
\hline $\begin{array}{l}\text { son's } \\
\text { earnings }\end{array}$ & $\begin{array}{l}.1060 \\
(.3931) \\
{[13143]}\end{array}$ & $\begin{array}{l}.0709 \\
(.3251) \\
{[10539]}\end{array}$ & $\begin{array}{l}.0135 \\
(.1502) \\
{[12333]}\end{array}$ & $\begin{array}{l}.0863 \\
(.2855) \\
{[15960]}\end{array}$ & $\begin{array}{l}.0511 \\
(.2997) \\
{[19466]}\end{array}$ & $\begin{array}{l}.0373 \\
(.1959) \\
{[13684]}\end{array}$ \\
\hline $\begin{array}{l}\text { son's } \\
\text { wages }\end{array}$ & $\begin{array}{l}.0812 \\
(.4039) \\
{[12518]}\end{array}$ & $\begin{array}{l}.0670 \\
(.4121) \\
{[10063]}\end{array}$ & $\begin{array}{l}.0056 \\
(.0836) \\
{[11694]}\end{array}$ & $\begin{array}{l}.0707 \\
(.3136) \\
{[15070]}\end{array}$ & $\begin{array}{l}.0454 \\
(.3572) \\
{[18422]}\end{array}$ & $\begin{array}{l}.0216 \\
(.1521) \\
{[12893]}\end{array}$ \\
\hline $\begin{array}{l}\text { son's } \\
\text { hours }\end{array}$ & $\begin{array}{l}.0005 \\
(.0056) \\
{[7231]}\end{array}$ & $\begin{array}{l}.0060 \\
(.0828) \\
{[5751]}\end{array}$ & $\begin{array}{l}.0068 \\
(.2278) \\
{[6828]}\end{array}$ & $\begin{array}{l}.0061 \\
(.0608) \\
{[9290]}\end{array}$ & $\begin{array}{l}.0034 \\
(.0601) \\
{[11321]}\end{array}$ & $\begin{array}{l}.0044 \\
(.0696) \\
{[8003]}\end{array}$ \\
\hline $\begin{array}{l}\text { daughter's } \\
\text { earnings }\end{array}$ & $\begin{array}{l}.1329 \\
(.3960) \\
{[9536]}\end{array}$ & $\begin{array}{l}.0762 \\
(.2808) \\
{[7292]}\end{array}$ & $\begin{array}{l}.0118 \\
(.1055) \\
{[8852]}\end{array}$ & $\begin{array}{l}.1027 \\
(.2730) \\
{[17717]}\end{array}$ & $\begin{array}{l}.0617 \\
(.2908) \\
{[21550]}\end{array}$ & $\begin{array}{l}.0562 \\
(.2372) \\
{[15093]}\end{array}$ \\
\hline $\begin{array}{l}\text { daughter's } \\
\text { wages }\end{array}$ & $\begin{array}{l}.0867 \\
(.4843) \\
{[9591]}\end{array}$ & $\begin{array}{l}.0545 \\
(.3765) \\
{[7353]}\end{array}$ & $\begin{array}{l}.0049 \\
(.0821) \\
{[8883]}\end{array}$ & $\begin{array}{l}.0543 \\
(.2706) \\
{[18008]}\end{array}$ & $\begin{array}{l}.0398 \\
(.3517) \\
{[21953]}\end{array}$ & $\begin{array}{l}.0242 \\
(.1914) \\
{[15293]}\end{array}$ \\
\hline $\begin{array}{l}\text { daughter's } \\
\text { hours }\end{array}$ & $\begin{array}{l}.0228 \\
(.0939) \\
{[4744]}\end{array}$ & $\begin{array}{l}-.0039 \\
(-.0199) \\
{[3594]}\end{array}$ & $\begin{array}{l}.001 \\
(.0012) \\
{[4409]}\end{array}$ & $\begin{array}{l}.0553 \\
(.2032) \\
{[5877]}\end{array}$ & $\begin{array}{l}.0138 \\
(.0899) \\
{[7142]}\end{array}$ & $\begin{array}{l}.0408 \\
(.2380) \\
{[5016]}\end{array}$ \\
\hline
\end{tabular}


Table A2 (continued)

\begin{tabular}{|c|c|c|c|c|c|c|}
\hline & $\begin{array}{l}\text { brother's } \\
\text { earnings }\end{array}$ & $\begin{array}{l}\text { brother's } \\
\text { wages }\end{array}$ & $\begin{array}{l}\text { brother's } \\
\text { hours }\end{array}$ & $\begin{array}{l}\text { sister's } \\
\text { earnings }\end{array}$ & $\begin{array}{l}\text { sister's } \\
\text { wages }\end{array}$ & $\begin{array}{l}\text { sister's } \\
\text { hours }\end{array}$ \\
\hline $\begin{array}{l}\text { brother's } \\
\text { earnings }\end{array}$ & $\begin{array}{l}.0853 \\
(.3510) \\
{[6966]}\end{array}$ & $\begin{array}{l}.0658 \\
(.3632) \\
{[6505]}\end{array}$ & $\begin{array}{l}.0127 \\
(.1574) \\
{[3754]}\end{array}$ & $\begin{array}{l}.0881 \\
(.2913) \\
{[15629]}\end{array}$ & $\begin{array}{l}.0576 \\
(.3570) \\
{[15661]}\end{array}$ & $\begin{array}{l}-.0008 \\
(-.0037) \\
{[7794]}\end{array}$ \\
\hline $\begin{array}{l}\text { brother's } \\
\text { wages }\end{array}$ & & $\begin{array}{l}.0562 \\
(.4160) \\
{[6157]}\end{array}$ & $\begin{array}{l}.0045 \\
(.0748) \\
{[3507]}\end{array}$ & $\begin{array}{l}.0689 \\
(.3055) \\
{[14841]}\end{array}$ & $\begin{array}{l}.0498 \\
(.4140 \\
{[14878]}\end{array}$ & $\begin{array}{l}-.0145 \\
(-.0889) \\
{[7376]}\end{array}$ \\
\hline $\begin{array}{l}\text { brother's } \\
\text { hours }\end{array}$ & & & $\begin{array}{l}.0091 \\
(.3396) \\
{[2166]}\end{array}$ & $\begin{array}{l}-.0021 \\
(-.0209) \\
{[8868]}\end{array}$ & $\begin{array}{l}-.0009 \\
(-.0168) \\
{[8865]}\end{array}$ & $\begin{array}{l}.0008 \\
(.0110) \\
{[4415]}\end{array}$ \\
\hline $\begin{array}{l}\text { sister's } \\
\text { earnings }\end{array}$ & & & & $\begin{array}{l}.0970 \\
(.2577) \\
{[4276]}\end{array}$ & $\begin{array}{l}.0562 \\
(.2799) \\
{[4300]}\end{array}$ & $\begin{array}{l}.0367 \\
(.1348) \\
{[2141]}\end{array}$ \\
\hline $\begin{array}{l}\text { sister's } \\
\text { wages }\end{array}$ & & & & & $\begin{array}{l}.0421 \\
(.3931) \\
{[4417]}\end{array}$ & $\begin{array}{l}.0031 \\
(.0213) \\
{[2187]}\end{array}$ \\
\hline $\begin{array}{l}\text { sister's } \\
\text { hours }\end{array}$ & & & & & & $\begin{array}{l}.0542 \\
(.2753) \\
{[1102]}\end{array}$ \\
\hline
\end{tabular}

\begin{tabular}{|c|c|c|c|c|c|c|}
\hline & $\begin{array}{l}\text { young } \\
\text { man's } \\
\text { earnings }\end{array}$ & $\begin{array}{l}\text { young } \\
\text { man's } \\
\text { wages }\end{array}$ & $\begin{array}{l}\text { young } \\
\text { man's } \\
\text { hours }\end{array}$ & $\begin{array}{l}\text { young } \\
\text { woman's } \\
\text { earnings }\end{array}$ & $\begin{array}{l}\text { young } \\
\text { woman's } \\
\text { wages }\end{array}$ & $\begin{array}{l}\text { young } \\
\text { woman's } \\
\text { hours }\end{array}$ \\
\hline $\begin{array}{l}\text { young } \\
\text { man's } \\
\text { earnings }\end{array}$ & $\begin{array}{l}.2430 \\
(1.0) \\
{[36630]}\end{array}$ & $\begin{array}{l}.1555 \\
(.8582) \\
{[35057]}\end{array}$ & $\begin{array}{l}.0365 \\
(.4523) \\
{[17390]}\end{array}$ & & & \\
\hline $\begin{array}{l}\text { young } \\
\text { man's } \\
\text { wages }\end{array}$ & & $\begin{array}{l}.1351 \\
(1.0) \\
{[33468]}\end{array}$ & $\begin{array}{l}.0103 \\
(.1712) \\
{[19180]}\end{array}$ & & & \\
\hline $\begin{array}{l}\text { young } \\
\text { man's } \\
\text { hours }\end{array}$ & & & $\begin{array}{l}.0268 \\
(1.0) \\
{[8922]}\end{array}$ & & & \\
\hline $\begin{array}{l}\text { young } \\
\text { woman's } \\
\text { earnings }\end{array}$ & & & & $\begin{array}{l}.3764 \\
(1.0) \\
{[18067]}\end{array}$ & $\begin{array}{l}.1449 \\
(.7217) \\
{[17626]}\end{array}$ & $\begin{array}{l}.2865 \\
(1.052) \\
{[7967]}\end{array}$ \\
\hline $\begin{array}{l}\text { young } \\
\text { woman's } \\
\text { wages }\end{array}$ & & & & & $\begin{array}{l}.1071 \\
(1.0) \\
{[17742]}\end{array}$ & $\begin{array}{l}.0190 \\
(.1308) \\
{[10036]}\end{array}$ \\
\hline $\begin{array}{l}\text { young } \\
\text { woman's } \\
\text { hours }\end{array}$ & & & & & & $\begin{array}{l}.1969 \\
(1.0) \\
{[3464]}\end{array}$ \\
\hline
\end{tabular}


Table $\mathrm{A3}$

WLs ratimates of Preference, Wage, Hours, and Earnings Equations with Restrictions on Wage and Bours Parameters in Earnings Equations

\section{Preference Equations (7):}

$$
\begin{aligned}
& u_{i b}=\underset{(.087)}{.193} u_{i f}-\underset{(.043)}{.008} u_{i m}+u_{i s}+u_{i b} \\
& \mathrm{u}_{\mathrm{ig}}=\underset{(.240)}{-.146} \mathrm{u}_{\mathrm{if}}+\underset{(.098)}{.367} \mathrm{u}_{\mathrm{im}}+\underset{\mathrm{is}}{ }+\mathrm{u}_{\mathrm{ig}}
\end{aligned}
$$

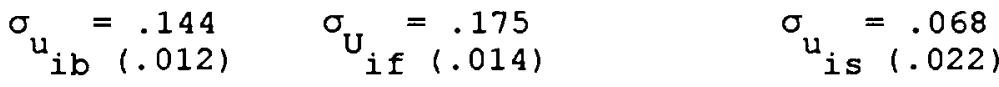

$$
\begin{aligned}
& \sigma_{u_{i g}(.016)}=\begin{array}{l}
.450 \\
(.016)
\end{array} \quad \sigma_{i m}(.016) \quad \operatorname{Cov}\left(U_{i f}, U_{i m}\right)=\frac{.015}{(.008)}
\end{aligned}
$$

\section{Log Wage Equations (5):}

$$
\begin{aligned}
& w_{i b}=\underset{(.039)}{.274} w_{i f}+\underset{(.047)}{.274} w_{i m}+w_{i s}+w_{i b} \\
& w_{i g}=\underset{(.046)}{.264} w_{i f}+\underset{(.048)}{.215} w_{i m}+\underset{(.215)}{.813} w_{i s}+w_{i g} \\
& \sigma_{\omega_{i b}(.013)}=.295 \quad \sigma_{w_{i f}}=.444 \\
& \sigma_{\omega_{\text {is }}}=.164 \\
& \sigma_{\omega_{\text {ig }}}=.259 \\
& \sigma_{W_{\text {im }}}(.007) \\
& \operatorname{Cov}\left(w_{i f}, w_{i m}\right)=.057
\end{aligned}
$$

Log Hours Equations (2):

$$
\begin{aligned}
& \mathrm{H}_{\mathrm{ib}}=\underset{(.015)}{.082} \mathrm{w}_{\mathrm{ib}}+\mathrm{U}_{\mathrm{ib}} \\
& \mathrm{H}_{\mathrm{ig}}=\underset{(.048}{.047)} \mathrm{w}_{\mathrm{ig}}+\mathrm{U}_{\mathrm{ig}} \\
& \mathrm{H}_{\mathrm{if}}=\left(\begin{array}{l}
.083 \\
(.027)
\end{array} \mathrm{w}_{\mathrm{if}}+\mathrm{U}_{\mathrm{if}}\right. \\
& \mathrm{H}_{\mathrm{im}}=\left(\dot{.045} \mathrm{w}_{\mathrm{im}}+\mathrm{U}_{\mathrm{im}}\right.
\end{aligned}
$$

Log Earnings Equations (3):

$\begin{array}{lll}E_{i b}= & w_{i b}+ & \mathrm{H}_{i b} \\ E_{i g}= & w_{i g}+ & \mathrm{H}_{i g} \\ E_{i f}= & w_{i f}+ & \mathrm{H}_{i f} \\ E_{\text {im }}= & \mathrm{w}_{\text {im }}+ & \mathrm{H}_{\text {im }}\end{array}$

Notes:

1. Standard errors are reported in parentheses.

2. $\mathrm{R}^{2}=.98$ (unweighted moments). RMSE= .9512. Sum of Squared Errors= 58.81. The model was fitted to 90 sample moments with 65 degrees of freedom. 3. The $p$ - value for the SSE drawn from a $x^{2}$ is .69, but this is the appropriate distribution only if the sample momen 65 are independent. 